\title{
Justice and Corporate Governance: New Insights from Rawlsian Social Contract and Sen's Capabilities Approach
}

\author{
Magali Fia ${ }^{1} \cdot$ Lorenzo Sacconi $^{2,3}$
}

Received: 23 May 2017 / Accepted: 6 June 2018

(c) The Author(s) 2018

\begin{abstract}
By considering what we identify as a problem inherent in the 'nature of the firm' - the risk of abuse of authority-we propound the conception of a social contract theory of the firm which is truly Rawlsian in its inspiration. Hence, we link the social contract theory of the firm (justice at firm's level) with the general theory of justice (justice at society's level). Through this path, we enter the debate about whether firms can be part of Rawlsian theory of justice showing that corporate governance principles enter the "basic structure." Finally, we concur with Sen's aim to broaden the realm of social justice beyond what he calls the 'transcendental institutional perfectionism' of Rawls' theory. We maintain the contractarian approach to justice but introduce Sen's capability concept as an element of the constitutional and post-constitutional contract model of institutions with special reference to corporate governance. Accordingly, rights over primary goods and capabilities are (constitutionally) granted by the basic institutions of society, but many capabilities have to be turned into the functionings of many stakeholders through the operation of firms understood as post-constitutional institutional domains. The constitutional contract on the distribution of primary goods and capabilities should then shape the principles of corporate governance so that at post-constitutional level anyone may achieve her/his functionings in the corporate domain by exercising such capabilities. In the absence of such a condition, post-constitutional contracts would distort the process that descends from constitutional rights and capabilities toward social outcomes.
\end{abstract}

Keywords Basic structure $\cdot$ Capabilities approach $\cdot$ Corporate social responsibility $\cdot$ Corporate governance $\cdot$ Entitlements and legal rights $\cdot$ Theory of the firm $\cdot$ Rawlsian theory of justice $\cdot$ Nash bargaining solution $\cdot$ Sen $\cdot$ Social contract

Abbreviations
CA $\quad$ Capabilities approach
WS $\quad$ Welfare state

Previous versions of this article have been presented at the EBEN Conference at Copenhagen Business School (Denmark) in October 2015 and at the 4th BERGAMO-WHARTON Joint Conference at the University of Bergamo (Italy) in July 2016. We thank two anonymous referees who have significantly contributed to its improvement.

Magali Fia

magali.fia@polimi.it

Lorenzo Sacconi

lorenzo.sacconi@unitn.it

1 Department of Management, Economics and Industrial Engineering, Politecnico di Milano, Milano, Italy

2 Department of Economics and Management, University of Trento, Trento, Italy

3 EconomEtica, Interuniversity Center, Università Milano Bicocca, Milan, Italy
CG Corporate governance

SC Social contract

NIE New institutional economics

GHM Grossman, Hart and Moore

TJ Theory of justice

SCTF Social contract theory of the firm

\section{Introduction}

The Social Contract (SC hereafter) approach constitutes a considerable line of thought in business ethics (Donaldson 1982; Keeley 1988, 1995; Freeman and Evan 1993; Dunfe and Donaldson 1995; Donaldson and Dunfee 1994; Sacconi 2000, 2006a, b, 2007; Heugens et al. 2006; Bishop 2008; Hsieh 2005, 2009). Nevertheless, some recent contributions, based on an analytical reconstruction of classic works in SC philosophy and, eminently, Rawls' Theory of Justice (TJ, hereafter), have forcefully asserted that the firm is not amenable to a SC analysis and justification. In particular, the 
Rawlsian TJ-because it is a theory of political institutionscould not provide a basis for understanding and justifying corporate governance (Mansell 2015; Singer 2015, 2016). According to this view, corporations do not enter the domains of the SC and TJ, and hence such theories are not appropriate for providing a theoretical framework to business ethics.

We do not intend here to undertake analysis of these critical arguments, or to engage in a direct confutation of them. Moreover, it is not our aim to enter a scholastic discussion about what Rawls (or any other classical SC theorist) 'really said' about the corporation - a subject that certainly was not central to A Theory of Justice (Rawls 1971). Even if Rawls had excluded the corporation from its domain, we would still think that there is a logical necessity for a SC theory of the firm (SCTF hereafter) and for studying its integration into the conception of justice in general. The first aim of this paper is hence to pose the problem in its most fruitful perspective, i.e., to ask the following questions: what is the internal logical necessity emerging from the economic analysis of the firm? By viewing the firm as an economic institution can we (or not) recognize the need for a SC theory? Has (or not) such a theory been provided to date? Is (or not) the logic of such a theory 'Rawlsian'? To all these questions, we shall answer positively. Then, once we have recognized that a 'Rawlsian' theory of the firm is not only needed, but at least in its general outline is already in place, we will also ask whether can it find room in the original formulation of the $\mathrm{TJ}$ as provided by Rawls himself, a question that we shall also answer positively.

More specifically, our starting point is a critical assessment of the new institutional economic theory of the firm (NIE hereinafter) - the best account that modern economics has given of corporations. Hence, by considering what we identify as a problem inherent in the 'nature of the firm' we make the case for the SCTF, which is truly Rawlsian in its inspiration (Sacconi 2000, 2006a, b, 2011a, b). We then link the SCTF (justice at the level of the firm) with the constitutional choice of the basic institutions of society that are the subject of the TJ (justice at the level of society). This leads us to consider how TJ can include the domain of corporate governance (CG hereafter). In fact, this relation still needs to be clarified given the apparently different locations of firms and the constitution respectively in the 'logical map' of the TJ, and especially the distinction between 'the basic structure' and institutions that do not belong to it directly. Although Rawls himself did not include corporations in the basic institutions of society, we propound the view of firms as institutions whose governance principles must be included in the constitutional design of society (i.e., the "basic structure").

This introduces only the first part of our contribution. What is most original about this article, in fact, is that we concur with Sen's aim to broaden the realm of the idea of social justice beyond what he calls the 'transcendental institutional perfectionism' of Rawls' theory (Sen 2009). Consequently, we further enlarge our 'Rawlsian' view of CG via Sen's capability concept (Sen 1992, 2009) by providing additional suggestions for capabilities' applications in the business domain. ${ }^{1}$ We maintain that rights over not only primary goods but also capabilities are (constitutionally) granted by the 'constitutional agreement' on the basic institutions of society. However, our focus is on the application of the capability approach (CA hereafter) to CG, as firms are post-constitutional institutions wherein stakeholders may turn capabilities into functionings. Examples are the achievement of a high level of functionings (and hence eudemonic happiness) in professional life, but also the achievement of basic functionings as in the case of an employee earning an income, health and social insurance, self-control and self-esteem. Such transformation processes are deeply affected by incomplete contracts and authority relations that shape the entire set of decision rights within the firm. Therefore, we argue that the SC, understood as the distribution of rights on primary goods and capabilities, granted at the constitutional level, should shape the principles of CG so that at the post-constitutional level anyone can achieve her/his relevant functionings in the corporate domain. This means that all the individuals participating rationally and responsibly in the firm, within the constraints posed by a structure of rights upholding anyone's capabilities, are enabled to attain their functionings in correspondence with their chosen capabilities and hence to reach a state of well-being. Lacking such a condition, post-constitutional contracts on the formation of various corporate organizations would distort the process that descends from constitutional rights and capabilities toward social outcomes.

Summing up, this paper contributes to the existing debates in three main respects. Its first contribution is to make the point about the existence of a SCTF, which is truly Rawlsian in its inspiration. The second is to link the SCTF (justice at the level of the firm) with the constitutional design at the level of society in general (Rawls' TJ). The third contribution is to further enlarge our 'Rawlsian' view of CG via Sen's capability concept.

Our argument progressively generalizes from the particular case of the firm (a particular institution) to the middle level analysis of how a constitutional contract would setthe the special matter of $\mathrm{CG}$, until reaching the even more abstract subject of the full integration of CG principles into

\footnotetext{
${ }^{1}$ Sen would not accept being considered a contractarian. However, Nussbaum already established connections between the CA and a Rawlsian perspective on constitutional choice, by suggesting that basic capabilities would be identified as the subjects of 'overlapping censuses' in a constitutional agreement worked out through the public use of reason (Nussbaum 2011, pp. 89-93).
} 
the TJ in general. A brief description of the paper's structure follows. Starting from the firm, Sect. "New-Institutional Economic Theory of the Firm and the Need for a Multistakeholder Governance Model" maintains that abuse of authority in the presence of multilateral specific investments is an unsolved problem inherent in the nature of the firm as seen through the lens of NIE. This invites a first consideration of the corporation's governance arrangement in light of the idea of justice, which suggests basing it on the SC among all the firms' stakeholders. Section "From the Micro-social Contract of the Firm to a Rawlsian Constitutional Contract" presents three subsequent models in the SCTF whereby CG enters the constitutional and post-constitutional design of economic institutions and we prove that the constitutional contract on CG can be designed from a truly Rawlsian perspective (see Appendix 1 on why Utilitarianism does not provide an equally satisfactory justification for the stakeholder approach). Section "Corporate Governance \& Rawls' Theory of Justice" enters the debate about whether firms can be part of the Rawlsian TJ in general; in consequence of the previous analysis, we show that CG principles are entitled to be considered part of the "basic structure." Section "Sen's Capabilities Approach and the Corporate Domain" constitutes the more innovative part of the paper and proposes an enlargement of the SCTF by showing how Sen's capabilities concept shapes CG (but see Appendix 2 for a clarification of why a capabilities metric is more fruitful for our subject than a resource-based metric). We provide here a new analysis of two meanings of capabilities as 'skills' and 'entitlements' and clarify how entitlements can be understood by means of a rigorous analysis of legal entitlements as freedom, positive and negative claim-rights. Then we interpret these entitlements as part of a CG design, pointing out how the capabilities of stakeholders (and employees in particular, but see Appendix 3 for an extension to customers) in the domain of CG constrain the notion of ownership of the firm. Section "Institutional Complementarities, and the Failure of WellBeing and Justice," finally, addresses the 'complementarity' among institutions at different levels in securing the aims of well-being and justice, and suggests the "Penelope's canvas paradox" to evidence what happens if CG and the institutions subjected to social justice are not integrated. The paper ends with the section "Conclusion".

\section{New-Institutional Economic Theory of the Firm and the Need for a Multi-stakeholder Governance Model}

\section{Hierarchies and the Abuse of Authority Problem}

In NIE, rooted in Coase's seminal work on the nature of the firm (1937) and developed through the concept of transaction cost minimization, the firm is defined as a unified mode of governance of transactions and represents an alternative to the coordination of transactions in the market. Roughly, firms emerge when the cost of using the market is greater than the cost of internal bureaucracy (i.e., authority relations). ${ }^{2}$ Developing this approach, Williamson (1975, 1986) introduced the concepts of 'contract incompleteness', 'opportunism' and 'specific investments' that characterize the resources employed in a transaction. Accordingly, when contracts are incomplete, and in the presence of specific investments, opportunistic behavior can affect the distribution of value among the parties by exploiting the unilateral or mutual dependence that investments create in their (idiosyncratic) relationships (Williamson 1986). Under these assumptions, transactions are doomed to failure in terms of efficiency losses (essentially due to the anticipation of the possibility of unfair treatment between contractual parties). In order to achieve a mutually beneficial exchange, the normative solution proposed by NIE (Williamson 1975, 1986; Grossman and Hart 1986; Hart and Moore 1990; Hart 1995) hence suggests a mechanism based on the allocation of authority (or internal hierarchy). Authority is here understood as the right to decide on matters not covered by the ex-ante contract (residual rights of control) and it affects the distribution of the jointly produced value. A party endowed with authority is able to obtain the execution of the ex-ante un-contractible decision that s/he prefers, but it must be carried out by the subordinate counterparty, essentially thanks to a (legitimate) threat of exclusion of this party supported by ownership of the firm. The normative solution proposed by NIE is then a 'unilateral hierarchical solution' in which authority is assigned to the person who makes the specific investment in order to maintain her/his incentives to invest. In fact, the non-controlling parties cannot make opportunistic threats to renegotiate the contract insofar as the controlling party, holding residual control rights, can dictate by fiat the disagreement outcome.

However, when specific investments are multiple and interdependent, one-side control will not prevent the risk of 'abuse of authority' (Sacconi 1999, 2000, 2011a). The individual (or class of individuals) who has the authority may protect her/his investment from expropriation, but at the same time may 'legally' expropriate other parties' investments by appropriating all the corporate surplus also deriving (by means of joint production) from other stakeholders' investments. The unilateral hierarchical solution is a 'second best solution' because it causes an inefficient outcome in terms of under-investment by the party that lacks authority

\footnotetext{
${ }^{2}$ Further seminal contributions to the analysis of the firm as essentially based on authority relations are Simon (1951) and Arrow (1974).
} 
and over-investment by the party that holds authority (Grossman and Hart 1986). But such inefficiency essentially boils down to expected unfairness and hence the fear of abuse of authority. Therefore, the risk of injustice-a threat to the legitimacy of authority in the corporate domain-is inherent in the unilateral solution of authority allocation (Sacconi 1999).

The problem persists under analyses of the different possible ownership structures of the firm that are apparently aware that each solution should account for the interest (minimizing contracting and governance costs) of many stakeholders (Hansmann 1988, 1996). However, the solution is still unilateral: taking each stakeholder's contract costs as given, it prescribes the allocation of authority to the particular stakeholder class that by exercising it minimizes (its) governance costs. But a stakeholder category's contracting costs normally depend on the unilateral exercise of authority by another stakeholder category. Thus, this solution leaves substantial contract costs to be shouldered by non-controlling stakeholders essentially because of the abuse of authority of the controlling one (e.g., in the case of capital investors' control, contract costs borne by human capital investors, i.e., employees). Such ownership structures lack legitimacy and hence are normatively unjustified and tend to be unstable (and to reach suboptimal equilibria). A need for a multi-stakeholder approach to CG hence directly ensues from the internal criticism of NIE.

\section{The Multi-stakeholder Model of CG}

In the perspective joining NIE (Williamson 1975, 1986; Grossman and Hart 1986; Hart and Moore 1990; Hart 1995) with the stakeholder approach (see Freeman 1984), the firm appears as team production among holders of specific investments, with some other stakeholders potentially subject to the (negative or positive) externalities deriving from it (Blair and Stout 1999; Sacconi 2000, 2006a, 2011a). The abuse of authority in the presence of multilateral specific investments and externalities then poses a challenge to the unilateral hierarchical solution. It vindicates the pursuit of a governance mechanism able to serve the interests represented by all the team members and to resolve the conflict over the distribution of the surplus flowing from team production, while minimizing negative externalities. The fair balance of all the interests at stake would then legitimize the proper exercise of authority associated with residual decision rights, as well as improving transaction costs efficiency with respect to the unilateral hierarchical control model. A response to the demand for a multi-stakeholder model of governance comes from the definition of CSR (Corporate Social Responsibility) as an "extended model of governance" whereby those who hold authority in the organization (board of directors/ top managers) have fiduciary duties that extend from those owed to the 'owners' to those owed to all other stakeholders (Sacconi 2006a). Specifically, the extended governance model is based on three elements: (i) the residual control right (ownership) allocated to the stakeholder with the largest investments at risk and with relatively low governance costs, as well as the right to delegate authority to professional directors and management; (ii) the fiduciary duties owed to owners by directors and managers, given that the former have delegated control to the latter; (iii) the fiduciary duties owed to non-controlling stakeholders by those who hold an authority position in the firm (owners, directors, and managers)-i.e., the obligation to run the firm in a manner such that (iiia) these stakeholders are not deprived of fair shares of the surplus jointly derived from specific investments, and (iiib) they are not subject to negative externalities (Sacconi 2006a). Fiduciaries' duties derive directly from the basic implicit agreement amongst all the corporate stakeholders that grounds the corporation as a unified governance system and rationally explains and legitimizes acceptance of the firm's hierarchical structure by the non-controlling stakeholders.

Although the above model is rather idealized, it offers a rational potential explanation of the emergence of several legal forms of corporations that have historically provided a balance among different stakeholders' interests. Such explanation is parallel to a justification for these historically observed forms of CG based on the idea of a fair and mutually advantageous stakeholders' agreement. Some examples are the American tradition of corporate law that understands the firm as a "mediating hierarchy" (Blair and Stout 1999; Stout 2012), the Co-determination model of German large corporations (Gelter 2009); the Japanese model of managerial capitalism (Aoki 2010), Benefit Corporations (Hiller 2013), and European social cooperatives (Sacchetti 2015). CSR self-regulations and policies can be also interpreted as attempts at the corporate level to introduce some balances that extend the governance mechanism by additional responsibilities toward non-controlling stakeholders (Sacconi 2006a, 2011a) .

\section{From the Micro-social Contract of the Firm to a Rawlsian Constitutional Contract}

In this section, we first ask the question concerning the normative justification of the multi-stakeholder model and answer that the SC perspective offers the best response. ${ }^{3} \mathrm{We}$ then show that from the basic idea of micro-level agreement among the corporate stakeholder, it is natural to ascend to

\footnotetext{
${ }^{3}$ See Appendix 1 on why Utilitarianism seems not to provide an equally satisfying justification of the stakeholder approach.
} 
a broader constitutional choice on the general principles. Then, according to the model of constitutional and postconstitutional contracts, we illustrate that such general principles are consequently applied at the micro-contract level. Thereafter we show that the constitutional (social) contract on CG principles is genuinely Rawlsian.

A first attempt to develop a normative foundation of the multi-stakeholder model of CG can be found in Freeman and Evan's seminal work (1993) in which they highlight the fiduciary relationships between the firm and all its stakeholders and the ensuing nature of the firm as a tool for coordinating efforts aimed at satisfying all the stakeholders' interests. A definition of CG and strategy based on the Kantian view is suggested: because all stakeholders are not merely means for the firm but also ends in themselves, their rights and interests should be pursued as corporate goals by the firm, and they should also participate in decisions affecting their interests (Freeman and Evan 1993). Similarly, other normative justifications of stakeholder theory (Donaldson 1982; Donaldson and Preston 1995) are based on the idea that a 'managerial' stakeholder approach should be consistent with a complex view of property rights, which includes not only claims to control and residual earnings but also the owner's constraints and responsibilities toward stakeholders. ${ }^{4}$ Neither of these formulations of the stakeholder model, however, provides a logical analysis of the stakeholders' agreement at the microlevel of the firm that - by exploiting the analytical tool of the theory of choice-is able to account for the fair and efficient agreement amongst the firm's stakeholders. This endeavor has been accomplished by the SCTF (Sacconi 1999, 2000, 2006a, b, 2007, 2011a, b) that analytically works out the firms' multi-stakeholder objective function that socially responsible firms maximize. That is the joint plan of action that corresponds to their agreement, solving their mixed motive interaction in which both mutual advantage for cooperation and distributive conflict are interlocked. SCTF in turn specifies the fiduciary duties owed to each stakeholder and the way in which different interests can be balanced and pursued. Thus, the SCTF provides a justification of the idea of CSR as an extended form of governance.

The stakeholder approach has been frequently criticized on the grounds that it is impossible for the corporate entity to pursue the many incompatible and separate interests of different stakeholder categories (Jensen 2001; Marcoux 2003; Mansell 2013; for a stakeholder-sympathetic view that, nonetheless, subordinates the distributive problem to the higher level objective of the company as such, hence not derivable form a combination of the stakeholders' interests, see; Leader 1999). But for the SCTF, the answer to this

\footnotetext{
${ }^{4}$ See Freeman et al. (2010) for the state of the art on stakeholder theory.
}

criticism is quite simple: an enterprise does not separately pursue the interest of each of the stakeholders. Rather, as an artificial actor (persona) aimed at solving problems of cooperation amongst different stakeholders, it pursues the joint plan of action (strategy) identified by the fair (Nash) bargaining solution to which these stakeholders would agree in an initial agreement (Sacconi 2000, 2006a, b). By no means is such a bargaining solution less defined or calculable than any profit maximizing strategy.

Besides the use of bargaining theory to model the SC (Gauthier 1986; Binmore 1998, 2005) and to understand cooperation in the firm (Aoki 1984), SCTF rests on an analogy between the multi-stage model of constitutional and post-constitutional contracts of the society at large (Buchanan 1975) and the inter-temporal model of efficient choice of firms' control structure based on the idea of contractual incompleteness (Grossman and Hart 1986; Hart and Moore 1990). This analogy suggests that the problems faced by the two theories, even though at different levels of abstraction, are essentially the same. The second inquires as to the reasons for accepting ex-ante a control structure that affects ex-post the renegotiation stage (always possible under incomplete contract) wherein final payoffs are allocated after specific investments have taken place. Similarly, the first analyzes the constitutional agreement on the allocation of rights and endowments that ex-post (in the post-constitutional stage) affects bargaining on the formation of specific productive coalitions and the final allocation of payoffs.

In the perspective of SCTF, we can distinguish three related models that explore the emergence of the firm with a governance structure composed of multiple fiduciary duties:

(i) a simple model at the micro-level of the firm, where the stakeholders agreement is decomposed into two steps: a pactum unionis for the creation of a multistakeholder association and a pactum subjectionis by which stakeholders agree on a governance structure;

(ii) a two-stage sequential bargaining model wherein at the first stage constitutional rules are agreed, so that at the second stage for any alternative rules arrangement a different post-constitutional game is played on the formation of different coalition structures (firms), according to which productive contributions are delivered and final payoffs allocated;

(iii) a game theoretical model of equilibrium selection, wherein the constitution must be selected in a 'state of nature' and the agreement 'under a veil of ignorance' provides the basic selection device; it reproduces Binmore's interpretation of Rawls' decision in the 'original position' and applies it to the stakeholders agreement on the constitution of the firm from 'state of nature' perspective. 
The progression from the first to the third model is functional to the aim of the paper. Exploiting Dunfee and Donaldson's distinction between "macro SC" and "micro SC" (Dunfee and Donaldson 1995), this progression traces the pathway that leads from the basic stakeholder agreement at the firm micro-level to the constitutional contract on CG principle that justifies and shapes such basic agreement. Then it brings us to the even more abstract debate on whether is it possible to fully integrate CG into the framework of Rawlsian TJ.

\section{The Basic Model of SCTF}

The first model is a firm micro-level agreement decomposable into two steps: the pactum unionis for the creation of a multi-stakeholder association, and the pactum subjectionis by which stakeholders agree on a governance structure. In this model (Sacconi 2006a, 2011a), at a first stage, stakeholders interact in a quasi-Hobbesian market scenario in which transactions among stakeholders are imperfectly regulated by incomplete contracts. Hence, they are subject to opportunism and end up in substantial failures of potential cooperation. The First SC of the firm (pactum unionis) is nothing more than a (Nash) bargaining agreement reached by all the stakeholders to exit the state of nature and set up a productive association (Nash 1950; Harsanyi 1977a). That is, they agree on a joint strategy that allows them to start a cooperative activity and team production without the threat that someone's investment may be expropriated because of the opportunist renegotiation. However, the association's governance costs (e.g., due to moral hazard in teams) are high, and they require a second agreement on a governance structure for the association. By means of a second SC of the firm (pactum subjections), the residual control right is delegated to the most efficient stakeholder in governance costs. Her/his authority, however, is constrained by a basic proviso of fiduciary duties owed to the non-controlling stakeholders deriving from the pactum unionis.

This model treats the firm as an apparently isolated and self-contained institution, emerging for an incomplete market and based on its own basic agreement. Nevertheless, in this model some fair terms-prior to the economic exchange regulated by the two agreements-are in some sense taken for granted. In fact, similarly to Gauthier's "Lockean proviso"'(Gauthier 1986), the status quo of the bargaining problem at the pactum unionis stage takes for granted that certain basic rights (including freedom and basic endowments) are symmetrically held by the parties. It is thus assumed that agents have symmetrical opportunities to take part in a basic associative agreement. Both of those terms are implied in the idea of symmetry of the bargaining game and the 'status quo' wherefrom the multi-stakeholder association is agreed-meaning that the set of strategic resources that agents own are similar, and that the minimal conditions that any acceptable associative agreement must grant to all stakeholders are similar too. Hence, the model works 'as if' a previous constitution had granted these basic rights and endowments to all participants in the foundation of the firm.

\section{(Partial) Constitutional and Post-constitutional Contracts}

The second SCTF model (Sacconi 2000, 2006b, 2011b, see also; Francés-Gómez 2003) proposes a two-tier contractarian theory of the firm based on backward reasoning in a sequential bargaining game (see also Brock 1979). Firstly, there is a constitutional stage where the parties establish an agreement (the 'constitution of the firm') on everyone's basic endowments of economic rights and duties concerning the use of production means. Secondly, there is a post-constitutional stage where economic interaction takes place and the parties have to agree on a 'joint strategy' for carrying out cooperation and team production with which a final allocation of payoffs is associated. The 'constitution of the firm' does not pick a single joint strategy and a particular payoff allocation directly; it only restricts the set of strategies open to each party in post-constitutional interaction. But because we know the solution for each post-constitutional bargaining game (shaped by a particular constitution), we may say that players solve the constitutional bargaining problem by comparing the post-constitutional solutions (and payoff allocations) from the perspective of the appropriate 'constitutional' solution. The criteria adopted in the two agreements are hence of prime importance. In the first agreement, the distribution of rights and duties is made before social production has occurred; thus distribution of basic economic rights should be made according to a principle applicable before the merit of any contribution can be claimed, i.e., the 'relative needs' criterion. From the mathematical viewpoint (and under the special assumption of interpersonal utility comparability) it is essentially identical to the Nash bargaining solution (Harsanyi 1977a; Brock 1979). In the second agreement, any agent decides whether to enter any cooperative coalition (firm) possible under the chosen constitution according to a distribution rule of the jointly produced surplus. That is, once the basic endowments have been fairly allotted, the surplus distribution should be then proportional to each party's contribution and personal responsibility for the value produced, i.e., proportional to the relative contribution. From the mathematical viewpoint, it is essentially identical to the Shapley value (Shapley 1953). The surplus is affected by both initial endowments-influencing the ability to carry out (specific) investment - and the actual contributions that the parties deliver to any cooperative coalition. In fact, the two mentioned principles of economic justice are 
mutually consistent and will both be reflected in the final payoffs' distribution.

This can be understood by reasoning backwards. Starting from each post-constitutional game, each individualhaving equal rational capabilities-properly employs her/ his endowments in order to profit as much as possible. Hence, each post-constitutional contract on the structure of productive cooperation under each constitution will entitle any participant to payoffs proportional to her/his potential contribution to any coalition. At the constitutional stage, however, agents compare the final distributions predictable across all the post-constitutional contracts from the perspective of the relative needs principle. Hence they select the one contribution-relative distribution that most satisfies also the need-relative proportionality. This model assumes that the bargaining space of the constitutional choice is symmetrical because it comprises all the logically possible allocations of control rights and endowments, i.e., for any given allocation that may advantage player A over player B, it includes also the symmetrical allocation that advantages player B over player A to the same extent. Therefore, the optimal constitution is selected by choosing amongst all the possible post-constitutional solutions the distribution of payoffs that maximizes the symmetric Nash bargaining function, i.e., applies the (efficient) egalitarian division rule. The final payoff distribution corresponds to a multiple fiduciary governance model wherein all the stakeholders are treated fairly.

So far we have furnished a reconstruction of how a twotier bargaining sequential cooperative game may give rise to a firm governance structure composed of multiple fiduciary duties (Sacconi 2006b). We call this model 'partial-constitutional and post-constitutional contracts' as it considers only a subsection of the overall constitution, i.e., the one pertaining to the constitution of the firm, assuming that it can be analyzed as a relatively autonomous institution with respect to the other institutions of society. However, the model still does not analyze this partial constitution in terms of an agreement emerging from a 'state of nature' interpretable as the "original position" in which the agreement is reached 'under a veil of ignorance,' so as to emphasize that the solution is consistent with a Rawlsian view on the constitution of CG.

\section{A Rawlsian View of the Constitutional Contract of the Firm}

The third model (Sacconi 2011a, b, 2013) fills this gap by introducing the assumption that the agreement on the firm's constitution is reached in a 'state of nature,' according to which CG forms are institutions traceable back to endogenously emerging norms (Posner 1997; Machey 2008), typically interpreted as Nash equilibria of a non-cooperative repeated game (Lewis 1969; Ullmann-Margalit 1977; Young
1998; Sacconi 2000; Binmore 2005). Consequently, only a subset of all possible institutional alternatives is feasible (the equilibrium solutions) and the choice of a constitution must be restricted only to this feasible set. However, equilibrium norms (Nash equilibria) are always multiple and hence the equilibrium selection problem remains. Moreover, feasible constitutions may be assumed to allocate control rights to one party or another, so that in the post-constitutional interaction the payoff-space of the game played under each feasible institutional alternative can result 'asymmetric.' This adds realism to the previous model by introducing arbitrary inequalities. In fact, authority observed in the business world is mostly asymmetrically allocated rather than equally split among all the parties. This nevertheless poses a problem for the theory as long as it seems that only constitutions that unilaterally allocate control according to a second-best solution can be selected.

Here Binmore's game theoretical reformulation of the Rawlsian 'veil of ignorance' and 'maximin principle' enters the scene (Binmore 1989, 1998, 2005). It consists of considering the $\mathrm{SC}$ under the veil as the appropriate equilibrium selection device. Under the veil of ignorance, any asymmetrical payoff-space (related to a constitution) is paired with its symmetrical translation by replacing the player positions symmetrically. This engenders a symmetric intersection set of feasible outcomes that are the equilibria affordable under both the representations of the payoff-space. Within this symmetrical subset the only rational agreement is the egalitarian bargaining solution. Since in asymmetrical payoff spaces, equality, if possible, typically most favors the worstoff party, the Rawls-Binmore egalitarian SC always selects a non-cooperative equilibrium coinciding with an application of the Rawlsian maximin principle.

Applied to the SCTF, the model, under the assumption that the corporate structure must belong to the set of possible (Nash) equilibrium institutions and that the veil of ignorance is the equilibrium selection device, shows that the constitution of the firm is chosen by comparing only egalitarian (equilibrium) solutions across the alternative constitutions feasible in the original position. Pareto efficiency only serves to order egalitarian solutions (Sacconi 2011b); accordingly, the best (Pareto dominant) egalitarian solution is selected notwithstanding any further consideration in terms of wealth maximization or efficiency that could concern non-egalitarian solutions. Mutual advantage thus only plays a role within the set of egalitarian solutions. This is a direct consequence of assuming that in the original position only (Nash) equilibria (i.e., stable) constitution can be selected, and requiring that selection must be made by agreement under impartiality and impersonality. Accordingly, the constitution selected, among those feasible, is the one that maximizes the position of the worse-off stakeholder (Sacconi 2011b). Roughly, even if institutional arrangements are 
unequal in terms of strategy opportunities allowed to participants, the payoffs corresponding to the selected equilibrium outcome are the distribution that maximizes the utility of the worse-off stakeholder.

The policy implication is straightforward: if self-sustainability (equilibrium) of the CG structure is required, then fairness must override efficiency, challenging the idea that firms should be committed only to efficiency. ${ }^{5}$ The proposed extended fiduciary duties model (as the best egalitarian solution) balances different interests requiring redress for the distributive consequences of the unilateral allocation of authority. If a party must be granted full authority to protect her/his incentive and promote efficiency, nevertheless s/he must be subject to the constitutional constraint to redress the non-controlling parties for any abuse of authority these parties suffer because of the extractive strategy of the party in the position of authority. Note that this result does not follow from wishful thinking but from the incentive compatibility condition implicit in the requirement of having stable institutions (equilibrium).

The second, and even more the third model of SCTF, represents the logical connection between the theory of the firm and the TJ. The second model shows how the constitutional contract may incorporate principles for the firm's control structure, while the third shows how this 'partial constitution' can be truly Rawlsian. Even though 'partial,' these constitutional contracts can be interpreted as part of the 'grand SC,' which is typically the subject of justice. The 'constitution of the firm' that results from the constitutional agreement restricts post-constitutional interaction (within which concrete firms are started) to those organizations that grant rights and duties according to the limits constitutionally stated. Thus, powers and prerogatives that the stakeholders will have in coalition formation, the choice of the joint strategy and the final distribution of the joint surplus will reflect the basic rights provided at constitutional level. In analogy to the methodology adopted by Donaldson and Dunfee (1995), we can understand the agreement on the economic constitution as part of the 'macro SC' concerning the economic principles that preside over subsequent interactions; while the second agreement, which operates at the level of business interaction, can be seen as a "micro SC. ${ }^{6}$

\footnotetext{
5 See Kaplow and Shavell (2009) for this idea in law \& economics, see also Singer (2016).

6 This analogy is however partial since Donaldson and Dunfee (1995) do not provide a sequential bargaining explanation of the 'macro/micro' SC.
}

\section{Corporate Governance \& Rawls' Theory of Justice}

\section{Rawls and the Firm}

Connecting the "micro" to the "macro" SC brings us to Rawls' TJ. For Rawls, 'the primary subject of justice is the basic structure of society, or more exactly, the way in which major social institutions distribute fundamental rights and duties and determine the division of advantages from social cooperation' (Rawls 1971, p. 7). Institutions pertaining to the basic structure of society distribute certain primary social goods, i.e., the means with which to pursue any rational plan of life. Social cooperation is characterized by 'moderate scarcity,' i.e., situations in which cooperation may produce a mutually advantageous joint surplus of each primary good, but parties have conflicting interests over its distribution. They then have to solve two simultaneous problems by agreement: a distributive conflict, and a collective choice problem concerning the selection of the best cooperative action enabling them to produce the maximum surplus. Rawls propounds the 'original position' as a model of choice on principles regulating how basic institutions distribute primary goods. This model solves those simultaneous problems, so that the basic structures must be seen as the set of institutions that enable cooperation in the production of a social surplus. It is formulated by developing an unanimous ordinal ranking of preferences on primary goods, represented as that of a single individual behind the veil of ignorance, hence an individual whose perspective is the same as anybody else's. The primary goods identified by Rawls are liberty and opportunities (political liberty, freedom of speech, liberty of conscience and thought, freedom of the person along with the right to hold personal property), powers and prerogatives of authority, income and wealth, and the bases for self-respect (Rawls 1971). The domain of justice is thus limited to basic institutions of society insofar as these institutions provide primary goods that are instrumental to any joint cooperative activity in society and at the same time have the authority to impose compliance with their principles on all those belonging to the political community regulated by them (Rawls 2001).

There is a debate on whether corporations can be candidates for entering Rawls' basic structure. On one side, we find Singer's contrary view (Singer 2015) who, adopting the view of the nexus-of-contract theory of the firm (Alchian and Demsetz 1972; Jensen and Meckling 1976), argues that firms are basically a voluntary form of association. Consequently, firms are not entitled to enter the basic structure because they do not have the power to inhibit exit from contracts by those who do not share their basic rules. This would be consistent with Rawls himself, who explicitly excluded private 
associations from the basic structure (Rawls 1971). On the other side, Blanc (2016), on replying to Singer, argues that CGs coercing citizens through labor law are entitled to enter the domain of basic institutions. Similarly, Arnold (2013) argues that corporations do not fit into the category of free association. ${ }^{7}$ To this debate we add the consideration that Singer's thesis is not supported by the main line of thought in transaction cost economics (even if he quotes Alchian and Demsetz). In fact, NIE-which from Coase, through Simon, Arrow and Williamson, extends to the GHM model and Aoki-maintains that allocation of authority, lock-in effects and complementarity of human resources are corporations' main characteristics.

\section{Corporate Governance Takes a Place in the 'Basic Structure'}

There are two main reasons to support the inclusion of firms (and CG) in Rawls' basic structure. The first is that firms distribute primary goods: they allocate power and authority, incomes and wealth, and the basis of self-respect (e.g., decent careers are means enabling people to be autonomous individuals integrated into society). Moreover, careers are open or closed to all according to how opportunities are set within firms (e.g., having managerial or technical careers depends on open employment procedures). The second reason rests on the more general criterion that establishes the boundary between the political object of the TJ and the associative domain that enters the sphere of what Rawls calls 'local justice.' Rawls limits the application of his principles of justice to the basic institutions operating in a society in which the legal system acts as a coercive order of public rules to regulate people's conduct and provides the framework (social institutions) for social cooperation (Rawls 1971). However, rules and practices governing private associations fall outside the scope of application of the principles of justice. In fact, associations guarantee people's exit freedom as they are characterized by voluntary relationships and not by coercion. Rawls considers firms as unimportant in the distribution of primary social goods as long as they are seen

\footnotetext{
7 Diverse criteria for the inclusion of institutions in the basic structure of society have been proposed. Among others, the functional criterion, first proposed by Freeman (2007) and then varyingly adapted by other authors (Heath et al. 2010; Taylor 2004), is based on the idea that institutions should be central to social cooperation. Then, O'Neill (2009) and Blanc and Al-Amoudi (2013) include institutions that have an effect on the distribution of primary goods. Hsieh (2008) identifies as a basic structure the level of economic democracy and in particular of workplace democracy, understood as the collective allocation of residual decision-making rights as long as it helps in achieving some further goal. Moreover, Néron (2010) investigates the role of corporations as distributive agents. Finally, Norman (2015) stresses the importance of ownership and governance in the TJ.
}

as free associations, from which individuals are free to exit if they are not satisfied in the pursuit of their life plans, subject to the general conditions of the economy. However, the NIE view of the firm concurs with the contention of Blanc (2016) and Arnold (2013) that corporations establish authority relations with employees; consequently, they cannot properly enter Rawls' free association category. In the perspective of NIE, corporations are institutions more similar to political ones than voluntary associations, being essentially hierarchical organizations that allocate authority. ${ }^{8}$ According to some prominent accounts (Hart and Moore 1990; Grossman and Hart 1986), authority is even based on a quite crude threat of exclusion from access to resources necessary for stakeholders to be able to profit from their specific investments. Hence, it entails the risk that they may lose the fruits of their investments (income and wealth at minimum, but some of the conditions of self-respect) that would allow them to pursue their life plans. Then allocation of authority impacts on the distribution of primary goods, and it may generate inequalities accordingly. Moreover, the substantial losses that someone would incur on exiting (or being excluded from) the corporation in which s/he has made specific investments are analogous to the sanctions someone could incur in order to exit a political community. The conclusion is that firms should be excluded from the domain of the TJ if and only if they actually act as free associations without allocating authority and without exercising threat power. But in this case, the firm would not exist, at least according to the efficiency explanation provided by NIE. This reasoning in terms of economic analysis gives more substance to the idea that 'private orderings' are not simply market ones, and corporations involve substantial exercise of power. Given this interpretation, we define firms as entities that enter the domain of social justice theory. This furnishes a basis for understanding the principles regulating $\mathrm{CG}$ as part of the design of the constitutional contract of society. In turn, this also supports the adoption of the two-step SC model for the emergence of the firm in its 'micro-macro' interpretation previously presented. The first step, at the macro level, consists in the choice of the principles for CG in line with general principles of justice. The second step, at the micro-level, is to select concrete firm forms according to contingencies and an efficiency analysis, but always granting that firms are shaped by principles of justice established at the first step. Of course, this interpretation does not provide a complete application of the two Rawlsian principles of justice to CG. However, we do not want to go further into the details of a debate on the possibility of giving a complete account

\footnotetext{
${ }^{8}$ See also Anderson (2015), where the point is made even more sharply by contending that contemporary American corporations have become 'private government.'
} 
of CG in terms of Rawls' principles of justice. Rather, by following Sen (1981, 1992, 1998, 2009), in the next section we focus on whether it is possible to exploit his suggestion to broaden the realm of social justice beyond Rawls' theory in a way that is suitable to the project of integrating CG in the 'idea of justice.'

\section{Sen's Capabilities Approach and the Corporate Domain}

In this section, we adopt a syncretic approach between Sen and Rawls, introducing Sen's capabilities concept as a fundamental element of the constitutional and post-constitutional contracts concerning the institutional ordering of CG. At the same time, we interpret Sen's criticism of Rawls' institutional perfectionism as indicating an excessively narrow application of the TJ. This criticism further legitimizes the claim that principles of justice, accepted at the constitutional level, may shape a set of institutions broader than that admitted by Rawls, specifically CG.

Attention has recently been paid in the business ethics literature to Sen's CA. Examples are the works investigating the impact of corporations on human well-being, focusing on the enterprise's goals and consequences in terms of capabilities and functionings (Shrivastava and Selvarajah 2016; Garriga 2014; Renuard 2011). Moreover, CA has received attention from the management literature focused on labor market issues and employees' welfare; see Westermann-Behaylo et al. (2016) for a brief review. Westermann-Behaylo et al. (2016) also contribute to the debate by appealing to Sen's $\mathrm{CA}$ in the context of stakeholder management and CG. ${ }^{9}$ Others focus on the theoretical foundations of economics and business, rethinking their anthropological assumptions based on CA (Giovanola 2009), or on improving the fit between virtue ethics and business ethics (Bertland 2009). We depart from this literature by focusing on the entitlement component of CA and its relation to CG, thus providing the missing link between CG and Sen's 'idea of justice.' ${ }^{10}$

\footnotetext{
9 Westermann-Behaylo et al. (2016) also argue that firms have an effect on the human dignity and capability of their stakeholders and advance a management model grounded in stakeholder theory integrated with Sen's concept of capabilities. The idea is that "a firm can include the capabilities approach in its overall strategy and operations"(p. 534). They also provide interesting examples of how the firm's operation may negatively/positively affect stakeholders' capabilities, e.g., the impact on tobacco consumption of customers' cancer or the firm's work/life balance policies for its employees. However, our argument here is focused on the entitlement component of capabilities and its relation to CG (as allocation of rights and duties), rather than on the effect of firms' strategy/policies on stakeholders' capabilities.

10 On private governance mechanisms and CA in global economy see however Kalfagianni (2014).
}

\section{Capabilities and Primary Goods}

Sen's seminal work shifts the Rawlsian emphasis from primary social goods seen as open-ended means (or resources) to consideration of the actual opportunities of living, seen as ends (Sen 1992, 2009). ${ }^{11}$ The central idea of Sen's wellbeing theory is the concept of capabilities and functionings. Functionings are states of 'doing and being,' i.e., what a person manages to do or to be; capabilities are defined derivatively as the set of achievable functionings. While the achieved functionings constitute a person's well-being, capabilities reflect the freedom to choose among them (Sen 2009). Specifically, well-being is not derived from the subjective pleasure given by goods consumption; rather, it is linked to the 'objective' functionings that a person is able to realize within the set of her/his capabilities (i.e., potential functionings), and it depends on her/his personal choices. The concept of capability can be seen as the opportunity to use goods in order to achieve the internal standard of excellence in every given field of human activity. That is to function properly in a given domain of human life, e.g., to be well-fed, be a good engineer, take part in community life, etc.. Hence for Sen the capabilities to achieve functionings, rather than the Rawlsian primary social goods (or resources), are therefore the basic terms of a metric of justice.

Given the considerable discussion amongst Rawlsian philosophers raised by the proposed shift from resources to capabilities and functionings, one may question how we succeed in making Rawls' and Sen's perspectives mutually consistent in the context of our research. ${ }^{12}$ However, not even Pogge, who mostly criticizes the CA from the perspective of an institutionalist TJ, denies the importance of capabilities and functionings at least as heuristic tools. In fact, a distribution of resources unable to guarantee some fundamental functionings to the worst-off members of society would suggest either that the adopted distributive rule should be reconsidered or that the current analysis of what counts as primary social goods is inadequate (Pogge 2002, 2010). Nevertheless, in the CA any inferior level of natural endowments in whatever ability, lack of talent or handicap counts as a relevant disadvantage. Since the CA requires

\footnotetext{
11 Sen criticizes primary goods as inflexible metrics of justice because people may have different abilities to convert goods into actual ways of doing or being in their lives, i.e., they do not take the diversity of human beings into account, thus ignoring real differences (Sen 1980).

12 See the book Measuring Justice (Brighouse and Robeyns 2010) with relevant essays by Pogge (Pogge, 2010), Kelly (Kelly, 2010), Anderson (Anderson, 2010), Arneson (Arneson, 2010) and Sen himself (Sen, 2010). However, as specified in note 1, Martha Nussbaum (2011) has already suggested an approach to fundamental functionings and capabilities in constitutional law that interprets them as resulting from a Rawlsian 'overlapping consensus.' See also Basu and Kanbur (2009).
} 
consideration of compensation for any of these inequalities as a claim of justice, Pogge contends that capabilities are not the basis for a metric of justice. In fact, someone who is less endowed with some ability may be better endowed with some other. Therefore, in order to compensate such inequalities, all natural capabilities should be compared and ordered according to some ranking principle. Hence, the opportunity cost of any improvement in one and loss in another capability should also be calculated. Rightly, therefore, Pogge maintains that not even Sen has proposed such a general criterion of social ordering, but limits his analysis of well-being to unanimous but incomplete orderings of combinations of very few and basic functionings wherein each is taken in monotonically increasing quantities.

Nevertheless, Anderson (2010) draws a fundamental distinction between a metric of justice and the choice of a rule of distribution. Specifically, she points out that Pogge's problem pertains to a particular choice of the distributive rule, i.e., a rule of overall compensation of any capability inequality as unjust. ${ }^{13}$ Such a problem could not be raised in regard to Nussbaum's list of 'constitutional capabilities and functionings' (Nussbaum 2011) or a 'sufficientarian' criterion. In fact, according to the latter initial unequal capabilities have to be improved just to reach the threshold that satisfies the requirement of putting everyone in the condition of exercising equal democratic citizenship (Anderson 1999, 2010). Democratic equality sets an independent standard that avoids the problem of a complete social ordering of all possible capabilities. Moreover, it is 'Rawlsian' in inspiration as far as it points to the subsets of capabilities corresponding to Rawlsian higher order interests of free and equal persons to develop: (i) the capability of developing a sense of justice, i.e., to adhere to just institutions; and (ii) the capability of choosing a rational plan of life (Rawls 1980). On the contrary, a justice metric based on functionings and capabilities would be richer and more informative than that based on resources, since it considers interpersonal variations (in personal characteristics, physical environments, or local social norms). In fact, such variations may substantially affect the capability to accomplish functionings even though individuals are given equal shares of resources. Inequalities that may arise can be markedly unjust and correcting them may be essential in order to guarantee democratic equality. Accordingly, we exploit the capability metric to show that the lack of democratization and social responsibility in the domain of CG would dramatically hinder the potential functionings open to some persons (typically the firm's employees) to the unjust advantage of others (typically capital owners). This

\footnotetext{
13 In Anderson's words “The metric characterizes the type of good subject to demands of distributive justice. The rule specifies how that good should be distributed." (Anderson 2010, p. 81).
}

will occur even in the presence of a constitution that grants an equal share of socially primary goods and resources (providing people with some basic capabilities not yet extended to cover CG) (see Appendix 2). Our criterion for identifying such injustices is not indefinite, but consistent with the idea of a SC on the constitution of the firm. That is, with the idea of equal participation in the agreement providing the rules for productive activities that make the society a cooperative venture for mutual advantage, and, especially, with the idea of democratic equality in the economic sphere. ${ }^{14}$

\section{Capabilities as Skills and (Legal) Entitlements}

In this section, we provide a more precise analysis of the notion of capability needed for its use to make sense of CG in light of the idea of justice. The relationship between goods and functionings is explained by analyzing the goods' characteristics, i.e., the multiple elements into which they can be decomposed. ${ }^{15}$ The appropriate uses of such characteristics by means of a set of conversion functions allow individuals to realize a combination of functionings. The characteristics of a good, the conversion functions and the range of control over these functions define 'an agent's capability set.' Then, by choosing among such capabilities, an agent can transform a good into a 'realized functioning.' Each agent selects different conversion functions among those available to him/ her, and, for any choice, s/he obtains a vector of achieved functionings where each component shows the degree of achievement in the corresponding functioning. Hence, the process that leads from goods to well-being comprises many steps: (i) a set of characteristics of goods provides 'raw materials' for functioning; (ii) a set of transformation functions defines which functionings are objectively possible for an agent; (iii) a subset of these transformation functions defines what an agent is capable of; (iv) an agent's freedom of choice is exercised within the capability set under his/ her control; (v) by choosing some transformation functions within his/her capability set an agent realizes achieved functionings; (vi) achieved functioning vectors are weighed-up to establish levels of well-being.

\footnotetext{
${ }^{14}$ We thank an anonymous referee who enquired how we position ourselves in the debate on the relative advantage of a capability metric over a resource metric, and the distributive principle for redressing inequalities of capabilities. To exploit this opportunity completely, we have added Appendix 2, where we show how CA is more fruitful for understanding unjust inequalities in functioning that emerge from the domain of CG but would not be noticed on looking at the subject only in terms of resources. There we also show the parallelism between our contractarian approach to CG and Anderson's 'sufficientarian rule,' especially when her recent analysis of private government (cf. Anderson 2017) is considered.

15 The 'Characteristic approach' originates in K. Lancaster (1979).
} 
To transform characteristics into achieved functionings an agent must possess the right to access the characteristics, the ability to use them properly, and the freedom to choose whether to make such use according to her/his will. Thus, the object of a metric of justice is not directly the distribution of functionings; rather, it is the distribution to all of as large as possible sets of capabilities (limited by a constraining principle of just distribution, e.g., a sufficientarian rule) which are neutral with respect to the individual's life plan and his/her functioning choices. ${ }^{16}$ To summarize, functionings constitute the person's well-being, while capabilities are processes to transform resources into functionings, but also the individual liberty to obtain well-being (Sen 1992). ${ }^{17}$

Given that capabilities concern conversion processes and at the same time the freedom to achieve those things that a person values, we can view capabilities as opportunities

\footnotetext{
16 A note is in order here to explain the liberal meaning of Sen's CA. Capabilities are much more concrete and detailed than primary goods, which are open-ended in nature. Moreover, capabilities are correlated to a certain good's characteristics and to the functioning that can be generated starting from such characteristics, thus referring to a particular conception of what is a good functioning based on given characteristics. This raises the question of whether defining certain sets of fundamental capabilities might require already knowing the individuals' life plan, thus being at odds with the concept of the veil of ignorance. Our answer is 'no.' Granting to all a set of capabilities as large as possible means that everybody has the freedom to choose among different styles and ways of living, that is, to pursue their objectives - those things that they value. In other words, there is a set of very elementary and basic functionings that can be understood as preconditions for any life plan and that nobody could refrain from choosing. Beyond this, it is up to the individual to decide which capabilities to use within the set under his/her control. No doubt, the notion of functioning is reminiscent of Aristotelian eudemonia in so far as it suggests that any given human activity has an intrinsic/objective standard of excellence coinciding with a state of well-doing or well-being of the agent who achieves it (Sen himself acknowledges his indebtedness to Aristotle's idea of "human flourishing"; see Sen 2017 , p. 356). Nevertheless, there is no presumption of an objective hierarchy of functionings, defining a complete, objective and unique conception of the good life, that could be commanded by a communitarian tradition (MacIntyre 1984). The metric of justice simply suggests that having an as large as possible set of opportunities could be better for anyone, but in the end the actual selection of a particular vector of functionings within this set of opportunities is up to the individual.

17 The analysis undertaken so far does not yet establish a criterion according to which capabilities must be distributed or inequalities in natural or social endowments of capabilities be redressed. Sen does not provide a method for generating a complete orderings of functioning vectors from which a society could be asked to choose from; rather, he suggests the idea of public discussion and deliberation to reach agreement on a contingent list of capabilities. On the contrary, Nussbaum proposes a precise list of capabilities-but sees it as resulting from an overlapping consensus at constitutional level-and Anderson proposes the independent criterion of a sufficiency level of capabilities in order to satisfy the standard of democratic equality. Obviously, neither of these additional criteria depends on a communitarian version of virtue ethics.
}

formed by two components: (i) a personal ability of the subject ('skill') and (ii) the possession of valid title ('entitlement'), i.e., a legal right enforced by the legal system or by some other social mechanism (social norms). ${ }^{18} \mathrm{~A}$ 'skill' is a person's conversion function, and an 'entitlement' states how many components of the conversion functions set are under a person's control, thus defining the choice set from which the person is entitled to select a conversion function to realize her/his functioning. In our distinction, the 'skill' component of capabilities can be understood as personal competence or practical knowledge and ability, i.e., a de facto notion signifying that capabilities concern the ability to do something in practice. It is a personal attribute of the subject, understood as the pragmatic or psychological ability to do or to be, which may be natural but also improved or acquired through training or education. However, the skill component would be ineffective in the absence of a (legal) right sustaining it, i.e., a de jure notion to which we refer as the 'entitlement' component. E.g., an individual may have a natural predisposition for a skill but does not have access to training that skill; or s/he may have learned a skill but is not entitled to exercise it, with the consequence that $\mathrm{s} / \mathrm{he}$ does not control it. The concept of entitlement is evident in Sen's seminal work on famines (Sen 1981), where the lack of a capability to feed oneself is understood as a lack of entitlement to food, i.e., of the 'right to access to food,' and not so much a lack of food itself. For example, during the Bengal famine of 1943 food was available in the shops (and protected by the State) but people died because they did not have the legal right to access it (Sen 1981,p. 49); this lack of entitlement to food is precisely the juridical component to which we refer.

Therefore, entitlements are rights that sustain skills. They comprise three elements: Freedoms; Positive Claims; Negative Claims. To clarify how we use these entitlement concepts we borrow from Hohfeld's analysis of fundamental legal relations based on two pairs of opposed concepts: (i) 'privileges/claim-rights' (i.e., rights properly understood) concerning first-order legal relations, i.e., relations amongst parties ranging over actions on goods; and (ii) 'power /immunities' concerning second-order relations ranging over possible changes of more basic (first-order) legal relations (privileges or claim-rights) on goods. Both the pairs exhibit the same correlation with two basic logical opposition: (i) the opposition duty vs. absence of duty (freedom) in deontic logic, and (ii) the even more general opposition necessity vs. absence of necessity (possibility) in modal logic (Sumner 1987). Leaving aside second-order legal relations, an

\footnotetext{
18 Our distinction resembles, but does not coincide with, that between 'internal' and 'combined' capabilities (Nussbaum 2011, pp. 20-23).
} 
agent X's privilege concerning an action A is a freedom of $\mathrm{X}$ meant as the possibility (a permission) to perform the action A or make some use of a good (amounting to A). Such freedom is positively correlated with the absence of duties, understood as both absence of X's duty to refrain from doing $\mathrm{A}$, and absence of any other agent's duty to allow $\mathrm{X}$ to do A. For example, you may be free to speak in public, but nothing obliges anybody else not to start in the vicinity another public speech that may subtract someone from your audience-even if there is no prohibition that you organize your own speech there. Alternatively, you may be permitted to enter a wood, which means that you don't have a duty to stay out of the wood, but this does not mean that you may exclude anybody else from entering it. On the contrary, an agent $\mathrm{X}$ 's claim-right is a right in the proper sense meaning that $\mathrm{X}$ holds the valid claim that somebody else accomplishes or refrains from accomplishing an action $\mathrm{A}$ in relation to $X$, i.e., these other persons bear a duty to perform or to refrain from performing an action A toward X. E.g., if I am the wood's owner I hold an exclusive claim to keep others out of the wood, therefore they hold a duty to refrain from entering the wood. In general, claim-rights can be 'negative.' E.g., the right-holder can require the duty-bearer to 'refrain from' performing some action or from taking some good; this can be seen as a right of non-interference that limits someone else's freedom. Typically, an agent's property right on a good is a negative claim addressed to everybody else to refrain from taking the good without the right-holder's permission. Otherwise, claim-rights can be 'positive' requiring the duty-bearer to perform a positive action or provide some service to the right-holder, e.g., the duty to give access to the education system or to healthcare services.

Thus, a claim-right is correlated to a duty or the (legal) necessity for another person (the duty-bearer) to accomplish (or not) a given act toward the right-holder. On the contrary, a person's privilege is simply correlated to the non-existence of duties, or of (legal) necessity, either claimed by others toward her/him, or claimed by herself toward others, that may affect her/his relation with a good or an action on a good. Nobody bears any duty, the agent X's action A is simply a possibility permitted by the law.

Interpreting the entitlement component of capabilities according to this taxonomy, it is now evident that entitlements provide support to skills through a bundle of rights that grant access to, and use of the characteristics of goods in order to function. A capability as entitlement consists first of a privilege to access the characteristics of a good in order to apply a skill to it so that it is transformed into a proper level of functioning in a given activity. However, this privilege is not a right to exclude others from that good, and it does not prevent anyone else from having a symmetrical permission to access the good. Simultaneously, the entitlement component contains a 'positive claim' that the agent be given the training to form her/his skill to use the characteristic of goods that $\mathrm{s} / \mathrm{he}$ is permitted to access in order to function properly with it. Moreover, the entitlement contains also the 'negative claim' that whoever may have control over the relevant good cannot arbitrarily debar the right-holder from accessing the characteristic of that good (a claim of 'not excludability'). The 'access' is the necessary precondition for achieving a given functioning and ensures the related freedom to use the good.

\section{Capabilities as Entitlements in the Domain of Corporate Governance}

The set of freedoms, rights, and duties emerging from a CG structure are important because they define the real opportunities (capabilities) offered to all the individuals working within the firm. Consider the employee's right to have a say in the decisions that affect the possibility of profiting from the investment that $\mathrm{s} /$ he has made in (specific) skills. That is, for example, the worker's opportunity to participate in (and influence) a decision concerning the possible closure of the firm's sector in which s/he operates and through which s/he pursues her/his professional career. This constitutes a protection from possible abuses that may be perpetrated by the holder of residual control rights. The idea is that the capability (entitlement) to participate in these decisions can be seen as follows: (i) a negative claim not to be excluded from participation in a collective decision-making process; and (ii) a positive claim to receive the information necessary to take collective or individual decisions that may prevent the risk of being abused; and (iii) a (more basic) negative claim not to be excluded (without just cause) from accessing the physical assets of the firm that are necessary for an employee/worker to achieve the functioning. Hence, a dutybearer has the obligation not to deter the right-holder's additional permission/freedom to access the firm's assets and to participate in some decision process. A negative claim is an obligation 'to refrain' (not to act); here, it is an obligation to 'refrain from excluding' (unless 'just cause' exists). Namely, here a negative claim is an obligation to refrain from denying (not allowing) access. Admittedly, the first and third terms are somewhat awkward because they involve double negations, and hence turn out to be a support for an independent freedom (possibility) to access the same asset and the freedom (possibility) to participate actively in some decision processes. ${ }^{19}$

\footnotetext{
19 Our view of capability can be easily extended to other stakeholder categories. Specifically, we can think of the firm's decisions that may have a polluting impact on the local environment (e.g., harmful emissions); or ones that may affect the conservation and protection of biological and landscape diversity. The main stakeholder involved in such decisions is the local community. The entitlement dimension of CA would consist in the community's opportunity to participate in (and prevent) such decisions. This can be achieved, for example, by
} 
This makes sense of Sen's definition of capability as 'freedom.' The double negation in (i) and (iii) in fact entails that the worker's possibility (freedom as privilege) to access the company's assets and internal decision process, and to use them so as to achieve some valued functioning, are additionally protected by a belt of claims-rights. These claimrights ensure that no one, even if s/he has a special relation (i.e., ownership) with the firm's assets, can prevent the worker's access to assets from being a substantial freedom of choice. ${ }^{20}$

Note that a property right in general consists of a negative claim excluding any other person from given goods or resources. Within firms, it may consist of the claim to exclude non-owners from taking residual decisions on the use of given assets. Thus, one may ask how capabilities interact with property rights in the domain of CG. The above-identified double-negative claim works as a constraint on the Blackstonian idea of property in the case of ownership of the firm, that is on a 'wholesale' right to exclude anyone from a thing. ${ }^{21}$ Namely, we depart from the definitions of ownership as backed by the complete right to exclude anybody else from accessing and using the firm's

\section{Footnote 19 (continued)}

means of the presence of the community's representatives on a corporate supervisory board to which top managers report (under the dual governance model). In regard to the supply chain, suppliers may typically undertake specific investments (e.g., dedicated equipment and components, location-specific infrastructure, etc.). Large corporations can then exploit their suppliers' dependence through the ex-post renegotiation of incomplete contracts. Suppliers' well-being should then be promoted by the following capabilities/entitlements: (i) the negative claim not to be ex-ante excluded from a fair selection process; (ii) the positive claim to receive all the information necessary to participate in the selection procedure, and about potential conflicts of interest; (iii) The negative claim that the firm should refrain from exploiting its bargaining power by threatening to exclude the supplier from the contract when it has idiosyncratically invested its resources in the supply relation. The responsibility of corporations toward customers according to CA needs a more composite argument, to which we devote Appendix 3.

${ }^{20}$ Admittedly, Sen emphasizes the importance of freedom both as (instrumental) opportunity to choose how to function and as process of choice, i.e., the intrinsic value of having a larger rather than smaller choice set, within which one is not constrained to act but can do so as one wants. This is formulated in consequentialist terms by the distinction between achievement of 'comprehensive outcomes' vs. mere 'culmination outcomes' (see Sen 2009, p. 230).

${ }^{21}$ See Merril and Smith (Merril and Smith, 2001), on property in rem and its explanation in terms of 'bounded rationality.' We contend that it does not apply to the ownership of physical assets of a firm which are essential to many complementary-specific investments and instrumental to the functionings of many stakeholders. Here, our analysis of the legal correlate with Sen's 'capabilities' ranges over property rights and corporate law (a tentative extension to consumers' rights is given in Appendix 3). For legal analyses that correlate 'capabilities' with contract law and labor law see respectively Deakin (2006), Deakin (2009) and Del Punta (2015). physical assets. Thus, we see ownership of the firm's physical assets as a bundle of rights that are modulated so as to become compatible also with stakeholders' capabilities and consequently entail a notion of 'abuse' of authority. In turn, capabilities as entitlements consist of the claim to access some of these asset-characteristics in order to realize the stakeholders' functionings. Hence, the owner has only a conditioned right to exclude that is subject to certain restrictions that reflect stakeholders' legitimate claims of access. Such a right is therefore supportive of the opportunity to realize stakeholders' functionings.

Similarly to Hsieh's approach (2008) to meaningful work, in which employment relationships are characterized in terms of assignment of residual decision-making rights, we consider the capability to function properly in work as related to the allocation of authority. According to the two capability components presented above, we underline the central role of CG in affecting the individuals' real opportunities within firms to function in tune with their subjective skills/competences. Freedom to exploit such opportunities is protected through participation and information rights and, mainly, through the claim not to be arbitrarily excluded from access to the firm's assets, coextensively with the right not to be arbitrarily fired. Thus, 'abuse of authority,' which denies these rights, can be also understood as deprivation of the real opportunities that an individual has to achieve some basic functionings in the realm of work. ${ }^{22}$

\footnotetext{
$\overline{22}$ We admit (as two anonymous referees have suggested) that the CA extends to employees' further freedoms in the workplace besides those on which we have focused-e.g., free speech and political freedom, and the liberty to profess one's religious faith. Moreover, the CA may also suggest considering the employees' opportunity to exploit their capabilities to creatively innovate their jobs and their tasks, so as to function better in the domain of professional realization. With the wider extent of the idea of justice permitted by the CA with respect to what Sen calls 'Rawlsian institutional perfectionism,' we contend that the primacy of civil and political liberties would enter the workplace. It would consist in the freedom to profess one's political beliefs and religious faith with the sole limitation of not making the exercise of others' liberties impossible. Thus, we strongly maintain that the firm's regulations should protect employees from any requirement to support the employer's political opinions or to serve them. Democratic equality, as a sufficientarian criterion for just capabilities distribution (Anderson 1999), strongly militates against such an abusive transfer of administrative authority to the political subordination and control of employees by their employers. Concerning the capability to innovate one's job creatively, we understand it as employee entrepreneurship. The capabilities of individuals to innovate work processes creatively are conceivable as cooperating with others' capabilities with which they are complementary. That is, they help to achieve interdependent functionings in the domain of professional realization, and moreover they may be functional to the production of goods and services that are preconditions for customers' functionings. In fact, there is no reason to think that these capabilities are exercised in isolation or, worse, that they entail mutually incompatible accomplishments. On the contrary, mutual advantage and super-additivity of team production can result from work organization understood in terms of complementary capabilities development and conjoint functionings. However, we emphasize CG in this
} 


\section{Institutional Complementarities, and the Failure of Well-Being and Justice}

In this section, we consider Sen's capabilities as a basic element of the constitutional and post-constitutional contracts model including institutions located at different levels. This passage permits us to analyze the complementarity of institutions operating in different domains of society, with special reference to the negative repercussions that CG may have on social well-being if complementarity among these institutions does not work properly. ${ }^{23}$

\section{The Paradox of Penelope's Canvas}

Institutions are complementary because they affect one another by mutually providing the strategic environment within which each institutional domain of interaction reaches its state of equilibrium (Aoki 2001). Such equilibrium states have well-being consequences for individuals operating in each domain that affect the achievement of an overall state of well-being. This complementarity can therefore be normatively interpreted in terms of its effect on capabilities. Consider the role of a WS that grants initial endowments of primary goods and capabilities in pursuit of certain social justice goals concerning fairness in the distribution of wellbeing (e.g., access to education, health services, access to credit for families and entrepreneurs, workers' protection). At the same time, we have seen that firms also play an important role in creating and fostering certain opportunities relevant to justice. Firms distribute income and associated capabilities, such as being able to enjoy good health, being adequately fed, or having access to career opportunities. Moreover, by creating decent job opportunities, firms provide some basis for self-respect by making individuals able to be self-supporting, and by giving them the capability to participate actively in social life. Complementarity can then also be understood as the mutual effect that one institution

\footnotetext{
Footnote 22 (continued)

essay, and the idea that the freedom to develop and exploit skills in order for the employees to function properly in joint production requires a legal infrastructure consisting in multiple privileges (permissions) and claim-rights. A central statement in this perspective is that property rights in the corporate domain need reform. Such reform would not permit the exclusion of employees from decision processes. Moreover, it would not allow their unilateral exclusion from access to corporate assets, to the extent that these are essential tools for the employees' proper functionings. In so far as the discussion of employees' freedom is concerned, it seems that by arguing in favor of a quite substantial reform of corporate ownership and codetermination in $\mathrm{CG}$, we have gone a long way toward the ideal of individual self-determination and autonomy.

${ }^{23}$ For an extensive analysis of institutional complementarity and the role of CG, see Aoki (2001, 2010).
}

operating in its domain has on the capabilities engendered by other institutions in their domain, and vice versa.

In this and the following section, we give a proof to the contrary of this statement by pointing out the failures due to malfunctioning institutional complementarity. This is what we call the 'Paradox of Penelope's canvas': the work accomplished during the day by welfare institutions in forming capabilities, is unraveled during the night by market institutions (like firms) which debar essential capabilities in the domain of CG. Specifically, firms are post-constitutional institutional domains wherein many capabilities in their de facto (skills) and de jure components (entitlements) have to be turned into functionings by corporate stakeholders. The WS provides many skills before the individual enters the firms' domain, but without a constitutional design of the bundle of rights set in the firms' domain, and specifically on CG, abuse of authority will continue to cause capabilities deprivation. If the constitution fails to settle the entitlement component of capabilities in the CG domain, abuse of authority will still prevail; then the skill component of capabilities will be nullified and fail to serve the achievement of well-being goals, dooming also the WS to failure.

Some elementary micro examples follow. Consider an environmental engineer that performs environmental impact analysis of many activities and projects of the company where s/he is employed. Her/his profession typically incorporates an internal standard of perfection that concerns protection of a public good-the environment. In the language of Sen's theory, achieving such an internal standard means functioning well in the domain of professional activity. In order to achieve this functioning, the engineer needs a capability as skill, which s/he in fact possesses due to her/his high level of education and specialization as a scientist, but s/he also needs a capability as entitlement. That is to say that her/his environmental impact analyses will not be consistent with such an internal standard of excellence if $s / h e$ is not entitled to the final say on the content of her/his reports. The governance structure of the company should not allow any hierarchical superordinate manager or director to impose changes and manipulations in the report data. Otherwise, the governance structure and the authority distribution in the firm would entail a capability deprivation of the environmental engineer.

One can argue that satisficing the perfectionist ideal of a profession does not matter much in terms of basic functionings relevant to social justice. However, the argument can be straightforwardly extended: let us take the case of trained but not professional workers whose training is provided by the system of public schools. Their jobs allow them to earn enough income to support themselves and their families' living standards (basic functionings) and also to participate actively in social and community life (also basic functionings). In order to maintain these basic functionings, however, 
the employees must at least hold some monitoring rights, namely a capability - in the entitlement component-to check that the firm will continue to maintain their jobs, or to foresee organizational changes to which they will need to adapt or react preventively in order to avoid being arbitrarily fired. If these entitlements are lacking in the CG domain, their basic functionings are at risk. One can of course ask that the situation be repaired repeatedly by a new ex-post redistributive intervention of the WS. But because these skills are not paired with complementary capabilities as entitlements, nothing can prevent them from failing repeatedly in their transformation into achieved functionings. Institutions providing skills may continue to work during the day, but these capabilities do not achieve the required functioning because, during the night, the lack of complementary capabilities as entitlements in the CG domain makes them almost useless.

\section{A Matter of Imperfect Design of the Constitutional and Post-Constitutional Contracts}

The effect of institutional complementarity between the WS and the firm can be better explained by referring to the interactions between constitutional and post-constitutional levels according to the two-stage bargaining model presented in Sect. "New-Institutional Economic Theory of the Firm and the Need for a Multi-stakeholder Governance Model." Assume that the constitutional contract provides a WS that allocates primary goods and capabilities according to a needs-based criterion aimed at avoiding arbitrary inequalities. The post-constitutional stage follows and parties can negotiate on the surplus's distribution on the basis of their contribution within various specific productive coalitions. In the ideal case ('ideal constitutional design') at the second stage each equally rational individual offers her/his contribution on the basis of previously granted primary goods and capabilities. Thus, final remuneration according to the contribution principle also reflects the individuals' relative needs.

We now introduce a gap in the constitutional design. Assume that there is a post-constitutional negotiation within a corporation whose CG does not reflect any constraint consistent with the agreement on principles of justice settled at the constitutional stage. Namely, the firm's CG lacks precisely a proviso concerning equitable structures of rights and entitlements that would be complementary to the skills formed by other fundamental institutions (the WS). This gap allows abuse of authority to re-emerge. For example, at constitutional level, the individual is granted the freedom to have free or affordable high quality education, but s/he lacks recognition of certain rights that ensure that all participants have the same opportunities of access to positions of control or access to ownership of a firm's resources, or have fair decision rights on the organization of a productive coalition (i.e., a firm). Alternatively, the constitution does not impose on a party in the position of an authority the extended responsibility to prevent any risk of abuse of authority by a responsible conduct or by redressing the disadvantaged parties if abuse were to occur. This situation amounts to assuming that the menu of constitutional choices at the first stage (the feasible constitutions) lacks exactly the fair structures of rights in the domain of CG. E.g., it is not possible for agents to form certain coalitions or to occupy the pivotal positions in the structure of possible coalitions. Alternatively, due to the absence of certain rights, some agent is never decisive in choosing the size of a coalition or in forming a winning coalition. Then the marginal contributions of this agent cannot be decisive for the value of the coalition in which s/he is involved, and this sharply reduces the value that $\mathrm{s} / \mathrm{he}$ can expect to obtain from participation in post-constitutional contracts (Shapley 1953; Sacconi 2006b). This will obviously depress the investments and hence the contributions of the non-controlling parties, while over-incentivizing that of the controlling parties. According to the "unilateral hierarchical solution' (see Sect. "New-Institutional Economic Theory of the Firm and the Need for a Multi-stakeholder Governance Model"), the result will be that the remuneration according to contribution will be suboptimal, since incentives to invest also are sub-optimally protected. However, the perspective, which we take here, is that of justice: although the final distribution may reflect contributions, there is no correspondence with relative needs. The less protected parties will contribute less, well below what they would do if the right and responsibility structure of the firm reflected relative needs. Therefore, the final distribution will never show consistency of the two justice principles as required by the constitutional and post-constitutional contracts theory, i.e., one party will never be able to 'deserve what s/he really needs.' To reach a final distribution that approximates the constitutional egalitarian distribution principle, recourse to ex-post redistributive transfers will be required. However, given the costs of ex-post transfers it is likely that the result will not be equally good, or even as feasible, as the one that would have been engendered by direct consistency between the constitutional and post-constitutional stages.

To summarize, we may rephrase the result in the terms of the CA: primary goods and capabilities, granted at constitutional level, should shape the principles of CG so that at the post-constitutional level anyone's functionings may be achieved in the corporate domain by exercising such capabilities. ${ }^{24}$ In the absence of such a condition, post-constitutional

\footnotetext{
${ }^{24}$ At least those functionings promised as skill at the constitutional level or that require to satisfy the standard of 'democratic equality' also in the corporate sphere.
} 
contracts on the formation and management of various cooperative organizational forms would distort the process that from constitutional rights and capabilities leads to social outcomes. They would thus prevent the operation of these institutions from obtaining social outcomes satisficing the very idea of Sen's well-being as functioning realization.

\section{Conclusion}

In this work, we have proposed an 'Enlarged SC,' an agreement in the original position for the selection of principles for basic institutions of society (CG included), where institutions are identified in terms not only of the primary goods that they provide but also of the capabilities that they form and uphold. We have argued that CG should be subject to the constitutional contract on basic institutions by means of a constitutional settlement of CG principles able to guarantee a balance between entitlements (capabilities) of the nonowner and property rights of the owner. Owners should in fact have the right not to have their sphere of discretion violated, within the limits of the non-owner stakeholders' rights to participate in decision-making processes, have relevant information, or be protected by extended fiduciary duties. The positive argument shows that once principles of CG are established, with the endowments of rights, individuals enter the post-constitutional stage in which they face opportunities of cooperation, and in exercising such rights, they invest in and contribute to the social surplus. At this point, a remuneration reflecting contributions and personal responsibility would be justified as far as it is consistent with entitlements that allow anyone to achieve well-being. Conversely, the negative argument in terms of malfunctioning institutional complementarities (Penelope's canvas paradox) shows that a gap at the constitutional level, concerning principles of CG, would distort the complementarity of institutions in allowing the achievement of individual functioning and finally social well-being.

\section{Compliance with Ethical Standards}

Conflict of interest The authors declare that they have no conflict of interest.

Ethical Approval This article does not contain any studies with human participants performed by any of the authors.

Open Access This article is distributed under the terms of the Creative Commons Attribution 4.0 International License (http://creativeco mmons.org/licenses/by/4.0/), which permits unrestricted use, distribution, and reproduction in any medium, provided you give appropriate credit to the original author(s) and the source, provide a link to the Creative Commons license, and indicate if changes were made.
Appendix 1: Can the Normative Justification
of the Stakeholder Approach be Utilitarian?

One may wonder whether preference utilitarianism (Harsanyi 1977a) may provide a logical foundation for stakeholder theory given its solid rootedness in rational choice theory. In terms of rational choice models, what distinguishes utilitarianism from contractarianism? The latter formalizes the social contract as a multi-player strategic interaction-i.e., an ex-ante bargaining game under a veil of ignorance and an ex-post non-cooperative game of compliance, possibly affected by the ex-ante choice (Gauthier 1986; Binmore 2005; Sacconi 2006a, 2007, 2011a, b; Sacconi and Faillo 2010). The former instead sees moral choice as an impartial but sympathetic individual exercise of expected utility maximization, given a uniform probability distribution over all the possible personal and social positions that the decision maker can hypothetically occupy (Harsanyi 1977a). Even if these may seem innocuous preferences for choice models, they entail a significant difference with respect to the possibility of making sense of the corporation as an artificial construct that enables cooperation of many stakeholders. Utilitarianism would not see stakeholders as moral agents involved in reciprocal cooperation and pursuing a corporate joint strategy and goal. Instead it would see them as moral recipients-i.e., all those receiving the effects of the utilitarian management of the firm. But what could then be the moral treatment of stakeholders according to a utilitarian management?

First, let us take an act-utilitarianism perspective (like the theories of Bentham, Mill, and Henry Sidgwick: see Lyons 1965). Since act utilitarianism aims at maximizing the sum of all the concerned sentient parties' utilities (or the average sentient party's utility), utilitarian management would be involved in calculating every tiny and distant consequence of corporate action to whoever. These effects are not confined to stakeholders who have essential relations with a firm-like those who are lockedin because of their specific investments, or dependent due to the firm's monopsony position in the local labor market or supply chain, or the importance of negative or positive externality affecting them. Nor are they limited to those stakeholders who receive individually small but widespread and cumulatively important effects-like the single company contribution to global warming. Any tiny and sparse spillover effect of the corporate activities must be summed up as well. But a large global corporation may have a lot of these effects. Even more than in the case of national governments, a global corporation may have an indefinite number of 'utilitarian stakeholders' in the sense of subjects being affected by some tiny, distant 
and sparse consequences of the corporate action, maybe transferred through international commerce. Calculating all such effects may go well beyond the bounds of management rationality. This fact, in an act-utilitarian perspective, imposes serious limitations on managerial decisions, putting them in a sort of Buridan's Ass situation.

Even leaving aside this bounded rationality issue, however, a general remark seems to be necessary. Preference utilitarianism aims at maximizing the utility of a possibly non-existent 'average individual'—or 'average stakeholder.' There is no relation between this perspective and that of concrete stakeholders as separate centers of choice, participating in the firm's activity through ownership or contractual relationships, or receiving its immediate external effects and hence interacting through channels different than contracts (i.e., political action). Nevertheless, the cooperation amongst essential stakeholders is central for the functioning of the firm as a team production of goods and services, then distributed to the stakeholders' mutual advantage. This is not to discredit the utilitarian perspective from a moral viewpoint, but only to observe a descriptive mismatch between act utilitarianism and the institutional reality of the firm seen according to the stakeholder approach. Descriptively, if firms are cooperative ventures for mutual advantage, they need to be governed through corporate institutions at least accepted by those who have to cooperate with/in them. In general, this entails that they receive some accepted benefits for cooperation or indemnity for negative effects on them. Morally speaking, however, utilitarians do not pay much attention to the benefits given to these cooperating stakeholders, since they have no moral priority against the consequentialist goal of maximizing the average individual's utility.

Assume in fact that, by piecemeal analysis, we conclude that overall utility maximization would be better served by transforming paid employment into non-paid (or much less paid) free cooperation by volunteers and the firm into an NGO operating for some alternative social aim, benefitting groups of people who, given their social deprivation, have much more intense marginal utility variation from benefit with respect to the original corporate stakeholders (customers included). What could prevent the company from undergoing this transformation? While instrumental arguments could be considered (for example paid employment is needed if the same people or their relatives have to be capable of volunteering for some good cause), nothing of this would amount to an ethics inherent to the reality of the firm seen as stakeholders' organized cooperation for their mutual advantage.

A step toward a rule-utilitarianism view (Brandt 1979; Harsanyi 1977a, b; Hardin 1988), setting a generalized stakeholder-oriented corporate management rule-which can be ratified as in general conductive to overall utility maximization-seems therefore to be required. Rule utilitarianism is well defined for market interaction under perfect competition. If one accepts the rough approximation for general utility maximization provided by Pareto optimality (when interpersonal utility comparisons are not available), profit maximization at the corporate level is the general rule ratified by utilitarianism. In fact, perfect competitive market equilibria are Pareto optimal, and reaching a market equilibrium needs profit maximization at the firm level. But the very existence of corporations of non-null dimension in a world of incomplete contracts excludes that the economy is perfectly competitive.

Without perfect competition, however, there is no reason why utilitarianism should confine its moral justification to the profit maximization rule at the firm level. The demand for a generalized stakeholder-oriented management rule then surfaces as a true necessity. It could not be deduced from the simple observation of the conditions under which the economy reaches an equilibrium state (there are certainly market equilibria that do not maximize the social aggregate of utilities). Hence, the stakeholder management rule that, if followed by all the companies, would contribute to maximizing general utility should be worked out by considering comparatively under any rule the social composition effects of combinations of stakeholders' interests pursued at each corporate level. Then, what rule of stakeholders' management at corporate level would lead to overall utility maximization?

One possibility is to assess from the utilitarian viewpoint the constitutional and post-constitutional contracts (i.e., rules) of the firm, which mainly involve stakeholders in the strict sense, assuming the minimization of the relevant negative externalities (see our second model considered in Sect. "(Partial) Constitutional and Post-constitutional Contracts," and moreover Sacconi 2000, 2006b, 2011a). On the two-step view, companies run according to the micro-social contract amongst the involved stakeholders give each of them his/her Shapley value (his/her relative contribution to cooperation). Moreover, this must be a payoff obtained by operating within the limits of the fair constitution of the firm chosen at the constitutional contract level, which allocates basic resources, productive means, control rights and responsibilities according to the relative need principle. Hence, the final distribution reached according to the best chosen constitution will satisfy-beyond the Shapley value within each constitution-also the Nash Bargaining Solution across all the possible constitutions. The Nash Bargaining Solution selects a point on the Pareto Efficient Frontier of the space including all the final allocations defined for all the possible constitutions. Therefore satisfaction of the Paretian approximation of the utilitarian principle-acceptable when interpersonal utility comparisons are not available-also results under the two-step constitutional and post-constitutional view of the 
firm. A rule utilitarian then would not be too much dissatisfied with the rules devised for the two-step social contract of the firm. Nevertheless, under interpersonal comparability of utility, normally Utilitarianism differs from and is less egalitarian than the Nash Bargaining Solution (see Brock 1979; Rachmilevitch 2015).

An alternative view is the new-institutional theory of the firms' ownership proposed by Hansmann $(1986,1996)$. It suggests that there is a natural utilitarian approach to adjudicating the most appropriate ownership form for each context, once one assumes that "total wealth maximization" is a permissible approximation for the maximum general utility. In fact, for each case Hansmann selects the best (unilateral) ownership form (included the 'no property' rule instantiated by the no-profit organization) by comparing the aggregate transaction costs attached to any form (governance costs related to each allocation of ownership rights to a particular stakeholder plus contract costs still affecting the other stakeholders under such a form) and minimizing across them.

This is a typical-even if simplified-utilitarian approach. The overall aggregate value of transaction costs (and hence total wealth) is accounted for, without paying much attention to how they are distributed. It is possible then that the best solution in a particular case allocates ownership to a party that holds low governance costs, even if it induces significant contract costs for another party subject to the risk of abuse of authority. Hansmann, however, does not consider multi-stakeholder forms of governance. Hence, there is no room for reallocation of rights corresponding to the responsibility of the first party to minimize its abuse of the second party. But this raises the further objection of why should a stakeholder-undergoing the risk of abuse of authority-agree to enter voluntarily into any institutional form designed to provide the overall minimization of transaction costs, but not giving mutual or fair benefit to him/her. This in fact is the point where one recognizes the logical superiority of the social contract approach-making room for stakeholders as autonomous moral agents having separate lives to be lived (partly, at least, in the company)—over the aggregative utilitarian view point.

\section{Appendix 2: Why are Capabilities Better Than Resources to Make Sense of CG in the Light of Justice?}

We replicate here, in the context of our analysis of the place held by CG in the TJ, the typical argument asserting the superiority of a capability metric over the primary good metric. That is, the CA considers the inequalities in functionings actually achievable by different persons that may arise according to their interpersonal variations affecting capabilities, even if resources remain equal among them.
Those variations can be: (a) in the environment faced by the agents, that may induce different levels of difficulty in accomplishing the same functioning given the same abilities; (b) in personal characteristics that, given the same physical environment, may constitute talents or handicaps in the performance of some functionings, e.g., by affecting the capability to bear effort or attention needed for performing a task; (c) in the treatment that prevailing social norms reserve to persons, given the same environment and similar abilities, in terms of social approbation, stigma or discrimination for example against categories of persons who attempt to function in certain activities, e.g., women seeking success in professions traditionally reserved to men. Notwithstanding the same level of resources, these variations may induce dramatic inequalities in the capabilities to achieve relevant functionings.

Suppose now that the constitution provides for the egalitarian distribution of a limited series of primary social goods that, according to the literal reading of Rawls' theory, does not include multi-stakeholder rights in the sphere of CG (like democratization or participation rights in corporate control). Assume also that these goods are employed to provide people with capabilities as skills through publicly funded education institutions. Then, given the same skills based on the same share of primary goods, major inequalities in the opportunity that agents have to achieve significant functionings may still occur due to the above mentioned variations. Specifically, let us first admit that variations are ( $\left.\mathrm{a}^{\prime}\right)$ in the 'institutional environment,' rather than in the physical environment, that is, the legal ordering within which agents choose to exploit their opportunities to function. Hence, let agent $\mathrm{X}$ operate in a legal environment such that all goods beyond the primary ones are privately owned by someone else, so that for each good there is a valid claim against $\mathrm{X}$ to keep him/her out of it. And let on the contrary agent $\mathrm{Y}$ operate in a different legal environment, wherein there are many commons (i.e., public infrastructures) that $\mathrm{Y}$ has therefore the privilege to enter and to use for developing plans and achieving a good level of functionings. Undoubtedly, in the second environment agent $\mathrm{Y}$ disposes of many more opportunities than agent $\mathrm{X}$ in the first environment does. Secondly, admit that variation are $\left(b^{\prime}\right)$ in personal characteristics given the same legal environment and the same basic resources (devoted to education) and skills. Two individuals $\mathrm{X}$ and $\mathrm{Y}$ exhibit different personal characteristics, such as family names and their belonging to different family groups. The legal ordering however associates these characteristics to relevant legal relations and entitlements such as substantial ownership of significant hereditary financial wealth invested in corporate assets for $\mathrm{X}$ and no ownership at all for Y. Thus, some personal characteristics may count as a fortune for someone or a misfortune (a handicap) for someone else. Although they have the same skills and 
ability from education and training, the opportunity of the capital owner's son X to access the summit of a company he partly owns is wider than the opportunity to function in an entrepreneurial activity for $\mathrm{Y}$-she will more probably be subjected to hierarchical power in an organization notwithstanding her good skills. Hence, these persons hold significantly different capabilities in terms of freedom to access and use wealth in order to undertake plans in which they may try to function and in terms of protection of this freedom by means of rights excluding anybody else from wealth. Thirdly, admit that variation are $\left(\mathrm{c}^{\prime}\right)$ in treatment that prevailing social norms reserve to persons, even though skills are similar, there is equal control over basic resources, and substantial similarity in privately owned wealth. Hence let two agents $\mathrm{X}$ and $\mathrm{Y}$ live under a social norm system expressing strong social approbation for the conservation of family control over private companies. A social norm of nepotism may then support discrimination in internal careers. The son of a company owner $(\mathrm{X})$ is then socially approbated when he early accedes to a managerial position within the family company, while the same would be seen as inappropriate in the case of Y, having similar skills but no family relations with the owner. The skilled Y with no family connection with the company owner may even adapt her preference to these social norms, forgoing the aspiration to reach such positions, and possibly migrating to find fortune elsewhere.

Obviously, there is no necessity that all the capabilities inequalities instantiated by $\left(a^{\prime}\right),\left(b^{\prime}\right)$ and $\left(c^{\prime}\right)$ are indefinitely compensated (this would be liable to attack on the grounds of Pogge's critique-see Sect. "Capabilities and Primary Goods," p. 27). However we may ground the selection of a level of compensation for some of these capability inequalities on a sufficientarian rule, i.e., the satisfaction of a capability threshold only sufficient to the exercise of democratic equality (Anderson 2010) and which is independent of the possibility to carry out a complete social ordering of all the possible capabilities. We only need now to extend democratic citizenship to include the democratization of authority in workplaces and the multi-stakeholder socially responsible models of CG. Anderson herself suggests (even if implicitly) this extension in her recent book on private government (Anderson 2017). Contemporary large corporations are 'private governments' wherein employers exercise systematic and penetrating authority over important spheres of the employees' lives, from labor organization and wealth distribution to lifestyle. Such authority is based-thanks to regimes of dismissal freedom increasingly introduced by many national governments-on the continuous threat to exclude the employee from the company, and hence from the resources that $\mathrm{s} / \mathrm{he}$ needs for material subsistence and pursuit of any life plan. Under private governments there is neither accountability to the non-controlling stakeholders for this exercise of power, nor fiduciary commitment to exercise authority in the reciprocal interest of all the corporate stakeholders, especially those who invest idiosyncratically and hence face high costs for the exit option. Besides lacking significant exit options, employees also lack voice to protect themselves from abuse of authority within private governments.

Anderson, with an argument similar to ours on abuse of authority, does not deny the efficiency rationale for large corporations, but suggests that the unconstrained political power exercised by private actors is a form of domination and status inequality among persons occupying different layers in the corporate hierarchy. Inequality of status and domination, however, are the hallmarks of political (even if private) regimes opposing democratic equality. Anderson concludes that, in order to democratize private governments, not only should the exit options be strengthened but also constitutional freedom rights within the corporate domain should be enforced, and especially forms of democracy in the workplace e.g., through the introduction in America of the co-determination model (Anderson 2017, p. 142).

It is therefore not difficult to join the two sides of Anderson's inquiry (i.e., democratic equality and private governments) by concluding that the threshold of capabilities (as entitlements) that should be satisfied in order to grant democratic equality would include more employees' freedom in the workplace, more participation in work organization and employment condition decisions, protected by the claim-right of having a voice in the decision process, and supported by further claim-rights preventing exclusion at will from the company by arbitrary dismissal. We simply suggest that the agreement under the veil of ignorance on the constitutions of the firm converging on the symmetrical solution of ex-ante bargaining would allocate to stakeholders, and especially employees, the participation, information and protection rights against arbitrary dismissal that would substantially counterbalance the authority of shareholders, directors and top management. Such balanced entitlements would induce much less inequality in the distribution of the corporate surplus amongst stakeholders, and hence a more egalitarian distribution of the opportunity to pursue the achievement of any significant functionings. Recall, however, that such enhancement of employees' functionings would not be arbitrary and indefinite, as it corresponds to the unanimous social contract on the constitution of the firm.

\section{Appendix 3: The Obligations of Justice That Corporations Owe to Their Customers}

The CA also offers a new perspective on the obligations of justice that a corporation owes to its customers and clients. Instead of focusing on goods as tools for extrinsic desiresatisfaction (welfare), the CA emphasizes functionings and 
capabilities as the objective bases of customers' well-being. This eudemonic trait (see Sen 2017, p. 356) has dramatic implications:

a) Adequacy of goods (characteristics) to logically possible functionings. What the firm supplies to customers are not goods but goods' characteristics. These, under the proper choice of some (at least) logically possible transformation function, should enable the customer to achieve a significant level of functioning in a given domain of her/his lifewhatever the 'functioning' may be. Hence the subjective satisfaction of a desire that does not correspond (i.e., is not adequate) to any real achievable functioning should not be the goal of the firm/customer transaction.

b) Supporting the customer's capability formation. A good's characteristics cannot be transformed into any reasonable level of functioning if the relevant transformation function does not belong to the customer's capabilities set. Lacking such transformation function, the good would be useless with respect to the customer's well-being. Hence, it is the responsibility of the firm that supplies the good also to provide the information and education of the corresponding capabilities. Or, at least, not to sell to a client a good or service which s/he is known not to have the capability to transform in a proper functioning. In other words: "you shall sell to a customer only goods he/she has the capability to employ for his /her functionings."

c) Supporting the customer's freedom of choice. The well-being value of any consumption act is not associated only with the adequacy of the good's characteristics to available capabilities. It also depends on the free choice of that functioning within a set of multiple individual capabilities. Hence, supporting the consumer's capabilities must not be confined to the sole utilization function that entails the customer will buy the good. Instead, it should put a larger array of alternative capabilities at the customer's disposal, in order to allow her/him to decide how to function with the goods available in the market. In other words, the support of the customer's capabilities must not induce him/her to depend idiosyncratically—given her/his restricted capability set—on the single set of characteristics possessed by an item provided by a specific company. This would not count as support of the customer's freedom, but as a path to his/ her dependence on a specific supplier firm. Moreover, it is the responsibility of the company not to limit the customer's freedom of choice by imposing a pre-established model of consumption that may discourage the client from looking at different modes of use of certain goods. For example, by means of advertisement that propagates stigma for consumers who do not follow the fashion in their consumption model.

d) Do not exploit idiosyncratic customers' capabilities. The formation of capabilities may nonetheless require specific investments by the client, who spends effort on learning and on the development of specific skills related to the use of particular characteristics. By necessity, this may create idiosyncratic relations between the two parties (customer and supplier) aimed at the subsequent supply of certain characteristics corresponding to the developed skills of the customer. Such idiosyncratic relations should not be exploited by the firm for the purpose of expropriating the customer of so much value as to compromise his/her well-being. That is, after the customer's investment, the supplier by ex-post renegotiation should not set the price of the transaction so high that completing the transaction would put the customer (due to the opportunity-costs borne in terms of alternative functionings) in the position of achieving an overall functioning level (well-being) lower than what he/she would have been able to achieve if $\mathrm{s} / \mathrm{he}$ had not invested in that particular capability.

e) Enough supply to satisfy sufficient provisions of goods functional to the equal achievement of basic functionings at affordable prices for all. If basic functionings are involved in the customer/firm relations-such as having a decent level of nutrition, housing, health, education, mobility etc.--sufficient quantities of the corresponding goods' characteristics must be offered at prices under a given threshold, so that sufficient provisions of the characteristics necessary for equal capabilities in these basic functionings are affordable for all. Affordability for all of equal, sufficient quantities entails that any person is entitled (i.e., has the capability to access) to the characteristics needed to function (being well or doing well) in these basic fields of human life.

Admittedly, the four former responsibilities can be satisfied through the acknowledgement of entitlements to customers that consist in claims addressed to particular goods suppliers. But this is not true for the latter. It identifies an imperfect right for which there is no claim addressed to a single or precise provider of the good-unless the good is supplied under a monopoly regime. The claim is instead addressed collectively to all the members of an industry operating in the supply of certain goods in a geographical location, with reference to the relevant group of customers (village, region, nation etc.). As a whole, they are subject to the social responsibility of providing sufficient amounts of the goods at prices not above a given threshold, so that each individual may access an equal, sufficient level of each basic functioning. This of course may require public regulation of these industries, direct public provision of some services, or organization of these industries by means of non-profit enterprises.

As said, on the contrary, the previous four responsibilities identify customers' entitlements that may be construed as Hohfeld legal relations (Hohfeld 1917): (i) the positive claim-right that the goods supplied (especially under asymmetry of information on quality) contain the characteristics that customers may de facto transform into substantial 
levels of functioning; (ii) the positive claim-right of receiving the information and education necessary to develop the skills that allow customers to transform supplied goods into functionings, and moreover to generate a rich capability set within which the customer may freely choose; (iii) the negative claim-right not to be subjected to deceptive advertising aimed at activating unreflective 'frames of mind' under which models of consumption different from the only one mostly conducive to the seller's interests are stigmatized. Finally, consider the case of an idiosyncratic capability developed under the expectation that some goods will be normally provided at prices that make the intent to use them for functioning entirely reasonable in terms of its opportunity-costs (other functioning renounced). This situation entails (iv) the negative claim-right that the idiosyncratic customer's capability shall be not ex-post exploited by the good's supplier by imposing a price that would expropriate the customer's well-being. In other words, the right not to be excluded from accessing the required characteristics at a price such that the customer avoids the situation that had s/ he been informed about actual price conditions, s/he ex-ante would not have decided to invest in developing the capability under consideration.

\section{References}

Alchian, A., \& Demsetz, H. (1972). Production, information costs, and economic organization. The American Economic Review, 62(5), 777-795.

Anderson, E. (1999). What is the point of equality? Ethics, 109(2), 287-337.

Anderson, E. (2010). Justifying the capability approach to justice. In H. Brighouse \& I. Robeyns (Eds.), Measuring justice: Primary goods and capabilities (pp. 81-100). Cambridge: Cambridge University Press.

Anderson, E. (2015). Equality and freedom in the workplace: Recovering republican insights. Social Philosophy and Policy, 31(2), 48-69.

Anderson, E. (2017). Private government: How employers rule our lives (and why we don't talk about it), Princeton: Princeton University Press.

Aoki, M. (1984). The co-operative game theory of the firm. Oxford: Oxford University Press.

Aoki, M. (2001). Toward a comparative institutional analysis. Cambridge, MA: MIT Press.

Aoki, M. (2010). Corporations in evolving diversity: Cognition, governance, and institutions. Oxford: Oxford University Press.

Arneson, R. (2010). Two cheers for capabilities. In H. Brighouse \& I. Robeyns (Eds.), Measuring justice: Primary goods and capabilities (pp. 101-128). Cambridge: Cambridge University Press.

Arnold, D. G. (2013). Global justice and international business. Business Ethics Quarterly, 23(01), 25-143.

Arrow, K. J. (1974). The limits of organization. New York: WW Norton \& Company.

Basu, K., \& Kanbur, R.(Eds.). (2009). Arguments for a better world: Essays for Amartya Sen's 75th birthday. Oxford: Oxford University Press.
Bertland, A. (2009). Virtue ethics in business and the capabilities approach. Journal of Business Ethics, 84, 25-32.

Binmore, K. (1989). Social contract. I: Harsanyi and Rawls. The Economic Journal, 99(395), 84-102.

Binmore, K. (1998). Game theory and the social contract, Volume 2: Just playing. Cambridge, MA: MIT Press.

Binmore, K. (2005). Natural justice. Oxford: Oxford University press.

Bishop, J. D. (2008). For-profit corporations in a just society: A social contract argument concerning the rights and responsibilities of corporations. Business Ethics Quarterly, 18(2), 191-212.

Blair, M., \& Stout, L. A. (1999). A team production theory of corporate law. Virginia Law Review, 85(2), 247-331.

Blanc, S. (2016). Are Rawlsian considerations of corporate governance illiberal? A reply to singer. Business Ethics Quarterly 26(3), 125-143.

Blanc, S., \& Al-Amoudi, I. (2013). Corporate institutions in a weakened welfare state: A Rawlsian perspective. Business Ethics Quarterly, 230(4), 497-525.

Brandt, R. B. (1979). A theory of the good and the right. Oxford: The Clarendon Press.

Brighouse, H., \& Robeyns, I. (Eds.). (2010). Measuring justice: primary goods and capabilities. Cambridge: Cambridge University Press.

Brock, H. (1979). A game theoretic account of social justice. In H. Brock (Ed.), Game theory, social choice and ethics. Dordrecht: Springer.

Buchanan, J. (1975). The limits of liberty. Chicago: The University of Chicago Press.

Coase, R. H. (1937). The nature of the firm. Economica, 4(16), 386-405.

Deakin, S. (2006). 'Capacitas': Contract law and the institutional preconditions of a market economy. European Review of Contract Law, 2(3), 317 - 34 .

Deakin, S. (2009). The 'capability' concept and the evolution of European social policy. New Zealand Journal of Employment Relations, 34(1), 7-26.

Del Punta, R. (2015). Labour law and the capability approach. International Journal of Comparative Labour Law and Industrial Relations, 32(4), 383-406.

Donaldson, T. (1982). Corporations and morality. Englewood Cliffs, NJ: Prentice Hall.

Donaldson, T., \& Dunfee, T. W. (1994). Toward a unified conception of business ethics: Integrative social contracts theory. Academy of management review, 19(2), 252-284.

Donaldson, T., \& Dunfee, T. W. (1995). Integrative social contracts theory: A communitarian conception of economic ethics. Economics and Philosophy, 11, 85-112.

Donaldson, T., \& Preston, L. (1995). The stakeholder theory of the corporation: Concepts, evidence, and implications. Academy of Management Review, 20(1), 65-91.

Francés-Gómez, P. (2003). Some difficulties in Sacconi’s view about corporate ethics. Journal of Business Ethics, 42(2), 165-180.

Freeman, R. E. (1984). Strategic management: A stakeholder approach. Boston: Pitman.

Freeman, R. E., \& Evan, W. M. (1993). Stakeholder management and the modern corporation: kantian capitalism. In Beauchamp, T., \& Bowie, N. (Eds.) Ethical theory and business (3rd edn.). Englewood Cliffs, NJ: Prentice Hall.

Freeman, R. E., Harrison, J. S., Wicks, A. C., Parmar, B. L., \& DeColle, S. (2010). Stakeholder theory: The state of the art Cambridge: Cambridge University Press.

Freeman, S. (2007). Rawls. Milton Park: Routledge.

Garriga, E. (2014). Beyond stakeholder utility function: Stakeholder capability in the value creation process. Journal of Business Ethics, 120(4), 489-507.

Gauthier, D. (1986). Morals by agreement. Oxford: Clarendon Press. 
Gelter, M. (2009). The dark side of shareholder influence: Managerial autonomy and stakeholder: Orientation in comparative corporate governance. Harvard International Law Journal, 50(1), 129-134.

Giovanola, B. (2009). Re-thinking the anthropological and ethical foundation of economics and business: Human richness and capabilities enhancement. Journal of Business Ethics, 88(3), 431-444.

Grossman, S. J., \& Hart, O. (1986). The costs and benefit of ownership: A theory of vertical and lateral integration. Journal of Political Economy, 94(4), 691-719.

Hansmann, H. (1988). Ownership of the firm. Journal of Law Economics and Organisation, 4(2), 263-304.

Hansmann, H. (1996). The ownership of the enterprise. Cambridge, MA: Harvard University Press.

Hardin, R. (1988). Morality within the limits of rationality. London: Chicago University press.

Hart, O. (1995). Firms, contract and financial structure. Oxford: Clarendon Press.

Harsanryi, J. C. (1977b). Rule utilitarianism and decision theory. Erkenntnis, 11, 25-53.

Harsanyi, J. C. (1977a). Rational behaviour and bargaining equilibrium in games and social situations. Cambridge: Cambridge University Press.

Hart, O., \& Moore, J. (1990). Property rights and the nature of the firm. Journal of political economy, 98(6), 1119-1158.

Heath, J., Moriarty, J., \& Norman, W. (2010). Business ethics and (or as) political philosophy. Business Ethics Quarterly, 20(03), 427-452.

Heugens, P. P., van Oosterhout, J. H., \& Kaptein, M. (2006). Foundations and applications for contractualist business ethics. Journal of Business Ethics, 68(3), 211-228.

Hiller, J. S. (2013). The benefit corporation and corporate social responsibility. Journal of Business Ethics, 118(2), 287-301.

Hohfeld, W. N. (1917). Fundamental legal conceptions as applied in judicial reasoning. Faculty Scholarship Series, paper 4378.

Hsieh, N. (2005). Rawlsian justice and workplace republicanism. Social Theory and Practice, 31(1), 115-142.

Hsieh, N. (2008). Survey article: Justice in production. Journal of Political Philosophy, 16(1), 72-100.

Hsieh, N. (2009). The normative study of business organizations: A Rawlsian approach. In J. Smith (Ed.), Normative theory and business ethics (pp. 93-117). New York: Rowan and Littlefield.

Jensen, M. C. (2001). Value maximization, stakeholder theory, and the corporate objective function. Journal of Applied Corporate Finance, 14(3), 8-21.

Jensen, M. C., \& Meckling, W. H. (1976). Theory of the firm: Managerial behavior, agency costs and ownership structure. Journal of financial economics, 3(4), 305-360.

Kalfagianni, A. (2014). Addressing the global sustainability challenge: The potential and pitfalls of private governance from the perspective of human capabilities. Journal of business ethics, 122(2), 307-320.

Kaplow, L., \& Shavell, S. (2009). Fairness versus welfare. Cambridge, MA: Harvard University Press.

Keeley, M. (1988). A social contract theory of organizations. Notre Dame, IN: University of Notre Dame Press.

Keeley, M. (1995). Continuing the social contract tradition. Business Ethics Quarterly, 5(2), 241-255.

Kelly, E. (2010). Equal opportunity, unequal capability. In H. Brighouse \& I. Robeyns (Eds.), Measuring justice: Primary goods and capabilities (pp. 61-80). Cambridge: Cambridge University Press.

Lancaster, K. (1979). Variety, Equity and Efficiency. New York, NY: Columbia University Press.
Leader, S. (1999). Participation and property rights. Journal of Business Ethics, 21(2-3), 97-109.

Lewis, D. (1969). Convention. A philosophical study. Cambridge, MA: Harvard University Press.

Lyons, D. (1965). Forms and limits of utilitarianism. Oxford: Clarendon Press.

MacIntyre, A. (1984). After virtue: A study in moral theory (2nd edn.). Notre Dame: University of Notre Dame Press.

Mansell, S. F. (2013). Capitalism, corporations and the social contract. Cambridge: Cambridge University Press.

Mansell, S. F. (2015). Book review: rejoinder to Veldman's review of capitalism, corporations and the social contract: A critique of stakeholder theory. Sage UK: London, England.

Marcoux, A. M. (2003). A fiduciary argument against stakeholder theory. Business Ethics Quarterly, 13(1), 1-24.

Merrill, T. W., \& Smith, H. E. (2001). What happened to property in law and economics? The Yale Law Journal, 111(2), 357-398.

Nash, J. F. (1950). The bargaining problem. Econometrica, 18(2), $155-162$.

Néron, P. Y. (2010). Business and the polis: What does it mean to see corporations as political actors? Journal of Business Ethics, 94(3), 333-352.

Norman, W. (2015). Rawls on markets and corporate governance. Business Ethics Quarterly, 25(01), 29-64.

Nussbaum, M. C. (2011). Creating capabilities. Cambridge, MA: Harvard University Press.

O’Neill, M. (2009). Liberty, equality and property-owning democracy. Journal of Social Philosophy, 40(3), 379-396.

Pogge, T. (2002). Can the capability approach be justified? Philosophical Topics, 30(2), 167-228.

Pogge, T. (2010). A critique of the capability approach. In H. Brighouse \& I. Robeyns (Eds.), Measuring justice: Primary goods and capabilities (pp. 17-60). Cambridge: Cambridge University Press.

Posner, E. A. (1997). Standards, rules, and social norms. Harvard Journal of Law and Public Policy 21(101).

Rachmilevitch, S. (2015). The Nash solution is more utilitarian than egalitarian. Theory and Decision, 79(3), 463-478.

Rawls, J. (1971). A theory of justice. Cambridge, MA: Harvard University Press.

Rawls, J. (1980). Kantian Constructivism in Moral Theory. The Journal of Philosophy, 77(9), 515-572.

Rawls, J. (2001). Justice as fairness: A restatement. Cambridge, MA: Harvard University Press.

Renouard, C. (2011). Corporate social responsibility, utilitarianism, and the capabilities approach. Journal of business ethics, 98(1), $85-97$.

Sacchetti, S. (2015). Inclusive and exclusive social preferences: A Deweyan framework to explain governance heterogeneity. Journal of Business Ethics, 126(3), 473-485.

Sacconi, L. (1999). Codes of ethics as contractarian constraint on the abuse of authority within hierarchies: A perspective from the theory of the firm. Journal of Business Ethics, 21(2-3), 189-202.

Sacconi, L. (2000). The social contract of the firm economics, ethics and organization. Berlin: Springer.

Sacconi, L. (2006a). Corporate social responsibility (CSR) as a model of extended corporate governance, an explanation based on the economic theory of social contract, reputation and reciprocal conformism. in F. Cafaggi (Ed.), Reframing self-regulation in European private Law, Dordrecht; Boston: Kluwer academic, 289-341, downloadable as Liuc paper 142 (2004) https://paper s.ssrn.com/sol3/papers.cfm?abstract_id=514522.

Sacconi, L. (2006b). A social contract account for CSR as extended model of corporate governance (Part I): Rational bargaining and justification. Journal of Business Ethics, 68(3), 259-281. 
Sacconi, L. (2007). A social contract account for CSR as extended model of corporate governance (Part II): Compliance, reputation and reciprocity. Journal of Business Ethics, 75(1), 77-96.

Sacconi, L. (2011a). A Rawlsian view of CSR and the game theory of its implementation (part i): The multi-stakeholder model of corporate governance. In L. Sacconi, M. Blair, R. E. Freeman \& A. Vercelli (Eds.) 'Corporate social responsibility and corporate governance: The contribution of economic theory and related disciplines'. Basingstoke: Palgrave Macmillan).

Sacconi, L. (2011b). A Rawlsian view of CSR and the game theory of its implementation (Part II): Fairness and equilibrium. In L. Sacconi, M. Blair, R. E. Freeman \& A. Vercelli (Eds.), Corporate social responsibility and corporate governance: The contribution of economic theory and related disciplines. Basingstoke: Palgrave Macmillan.

Sacconi, L. (2013). Ethics, economic organisation and the social contract. In A. Grandori (Ed.), Handbook of economic organization: Integrating economic and organization theory (pp. 112-136). MA: Edward Elgar Publishing Northampton.

Sacconi, L., \& Faillo, M. (2010). Conformity, reciprocity and the sense of justice. How social contract-based preferences and beliefs explain norm compliance: The experimental evidence. Constitutional Political Economy, 21(2), 171-201.

Sen, A. (1980). Equality of what? In S. McMurrin (Ed.), Tanner lectures on human values. Cambridge: Cambridge University Press.

Sen, A. (1981). Poverty and Famines. Oxford: Oxford University Press.

Sen, A. (1992). Inequality reexamined. Oxford: Oxford University Press.

Sen, A. (1998). On economic inequality. Oxford: Oxford University press, Oxford.

Sen, A. (2009). The idea of justice. Cambridge, MA: Harvard University Press, Oxford.

Sen, A. (2010). The place of capability in a theory of justice. In H. Brighouse \& I. Robeyns (Eds.), Measuring justice: primary goods and capabilities. Cambridge: Cambridge University Press, pp. 239-253.

Sen, A. (2017). Collective choice and social welfare: Expanded edition. London: Penguin Books.

Shapley, L. S. (1953). A value for n-person games. In H. Kuhn, \& A. Tucker (Eds.) Contributions to the theory of games. Princeton, NJ: Princeton University Press.

Shrivastava, S., \& Selvarajah, C. (2016). Organisational justice: A Senian perspective. Journal of Business Ethics, 135(1), 99-116.

Simon, H. A. (1951). A formal theory of the employment relationship. Econometrica, 19, 293-305.

Singer, A. (2015). There is no Rawlsian theory of corporate governance. Business Ethics Quarterly, 25(1), 65-92.

Singer, A. (2016). Justice failure: Efficiency and equality in business ethics. Journal of Business Ethics, 28, 1-19.

Stout, L. (2012). The shareholder value myth. San Francisco: BerrettKoehler Publishers, Inc.

Sumner, L. (1987). The moral foundations of rights. Oxford: Oxford University Press.

Taylor, R. S. (2004). Self-realization and the priority of fair equality of opportunity. Journal of Moral Philosophy, 1(3), 333-347.

Ullmann-Margalit, E. (1977). The emergence of norms. Oxford: Clarendon Press.

Westermann-Behaylo, M. K., Van Buren, H. J., \& Berman, S. L. (2016). Stakeholder capability enhancement as a path to promote human dignity and cooperative advantage. Business Ethics Quarterly 26(4), 166-178.

Williamson, O. (1975). Market and hierarchies. New York, NY: The Free Press.

Williamson, O. (1986). The economic institutions of capitalism. New York, NY: The Free Press.

Young, H. P. (1998). Individual strategy and social structure, an evolutionary theory of social institutions. Princeton: Princeton University Press. 